\title{
Araneomorph spiders from the southern Carnarvon Basin, Western Australia: a consideration of regional biogeographic relationships
}

\author{
Mark S. Harvey ${ }^{1}$, Alison Sampey ${ }^{1,2}$, Paul L.J. West ${ }^{1,3}$ and Julianne M. Waldock ${ }^{1}$ \\ ${ }^{1}$ Department of Terrestrial Invertebrates, Western Australian Museum, \\ Francis Street, Perth, Western Australia 6000, Australia \\ ${ }^{2}$ Present address: Lot 1984 Weller Rd, Hovea, Western Australia 6071, Australia \\ ${ }^{3}$ Present address: Halpern Glick \& Maunsell Pty Ltd, John Tonkin Centre, \\ 629 Newcastle St, Leederville, Western Australia 6007, Australia
}

\begin{abstract}
A survey of the ground-dwelling araneomorph spider assemblages of the Southern Carnarvon Basin revealed a total of 33 families. Apart from the Gnaphosidae and Zodariidae which were not analysed due to timeconstraints, we recognized a total of 285 species placed in 146 genera. Very few taxa could be assigned to existing genera or species, reflecting poor taxonomic knowledge of many groups of spiders. Patterns in species composition across the study area were correlated with rainfall gradients, and a discrete claypan fauna was detected. Vicariance events seem to explain part of the patterning evident. However, strongly localised patterns in species composition were also evident.
\end{abstract}

\section{INTRODUCTION}

Araneomorph spiders constitute a large proportion of total arachnid diversity, with 90 recognized families and an estimated 35000 described species (Coddington and Levi, 1991; Platnick, 1997). They differ from all other spiders, the Mesothelae which consists of the sole Recent family Liphistiidae, and the Mygalomorphae which consists of the trap-door spiders and their relatives, by the orientation of the fangs which bite inwards.

The Australian fauna is represented by 68 families (R. Raven, unpublished data), of which 56 have been recorded from Western Australia (M. Harvey, unpublished data). Three of these - Agelenidae, Oecobiidae and Sicariidae - are solely represented by introduced species, leaving a total of 53 families of indigenous species. These 53 families are unevenly distributed across the State, with some restricted to the temperate south-west corner and others known only from the northern tropical regions. The total number of spider species expected for Western Australia is difficult to estimate, but $2000-3000$ species is predicted (M. Harvey, unpublished data).

Prior to our study, the spider fauna of the southern Carnarvon Basin had been examined only in an ad-hoc way (Table 1). The first published records were from the Michaelsen and Hartmeyer Expedition of 1905, which recorded 21 species from the southern Carnarvon Basin (Simon, 1908, 1909), collected at four terrestrial localities: Denham, Brown Station (on Dirk Hartog Island), Baba Head and Tamala (Michaelsen and
Hartmeyer, 1907-1908). Modern authors had contributed only a further nine species (Baehr and Baehr, 1987, 1992, 1993; Harvey, 1995; Hirst, 1991; Jocqué and Baehr, 1992; Levi, 1983; Main, 1987; McKay, 1975, 1979), although numerous additional species were known from the area, based mostly upon specimens lodged in the Western Australian Museum (M. Harvey, unpublished data). A recently published survey of the Lamponidae (Platnick, 2000) has recorded an additional 15 species from the area, mostly based upon specimens collected in the present survey.

This paper summarises the first quantitative assessment of patterns in the composition of the araneomorph spider communities in the southern Carnarvon Basin, Western Australia, based upon a detailed pitfall-trapping program conducted over a range of major geomorphological units of the study area. The composition of the spider community, represented by species occurrences, was analysed in terms of a number of physical environmental attributes to explain the variation across the study region.

\section{MATERIAL AND METHODS}

\section{Study Area}

The southern Carnarvon Basin study area covers some $75000 \mathrm{~km}^{2}$ situated on the central region of Australia's west coast. It is centred on Shark Bay and extends from the Murchison River in the south to the Minilya River in the north, and eastwards to beyond Gascoyne Junction (Figure 1). It covers the 


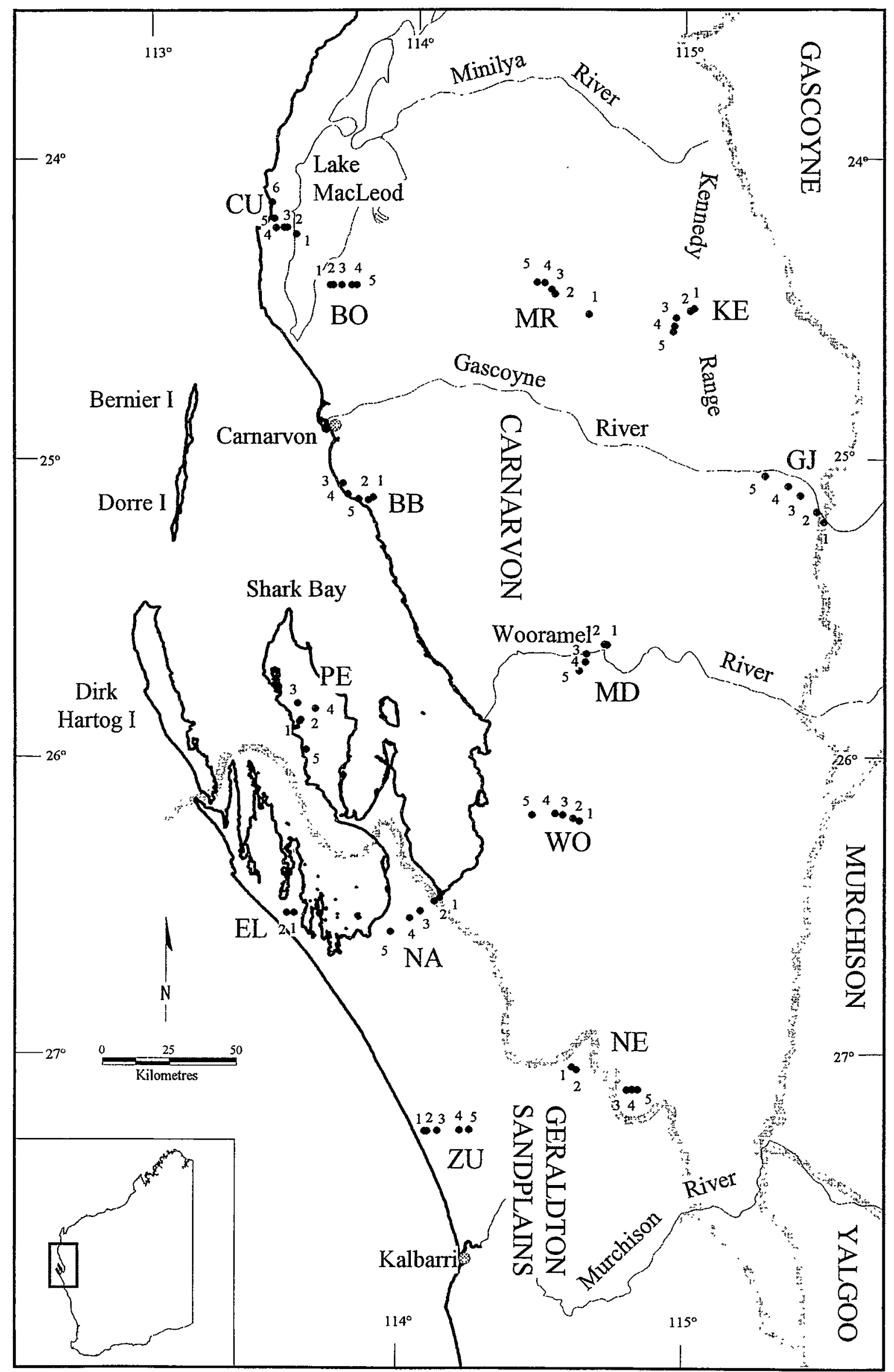

Figure 1 The southern Carnarvon Basin study area. The thirteen survey areas are indicated by two letter codes (see text), and at each area, the quadrat locations indicated by black circles. 
Table 1 Araneomorph spiders previously recorded from the southern Carnarvon basin.

\begin{tabular}{|c|c|c|c|c|}
\hline Species & Family & General distribution & $\begin{array}{l}\text { Distribution within southern } \\
\text { Carnarvon basin }\end{array}$ & Authority \\
\hline Argiope protensa L. Koch & Araneidae & Widespread across arid and semi-arid Australia. & $\begin{array}{l}\text { Some localities in or near study area, e.g. } \\
\text { Milly Milly, Newmarracarra Homestead, } \\
\text { Kalbarri, Gee Gie Outcamp, } \\
\text { Carrollgouda Well }\end{array}$ & Levi (1983) \\
\hline
\end{tabular}

Austracantha minax (Thorell)

Araneidae

Dolophones conifera (Keyserling)

Araneidae

Larinia eburneiventris Simon

Paraplectanoides cerula Simon

Clubiona laudabilis Simon

Clubiona robusta L. Koch

\section{Meedo houstoni Main}

Badumna candidus (L. Koch) (as Phryganoporus tubicola Simon) Badumna veliferum (Simon) (as Aphyctoschaema veliferum Simon) Homoeothele micans Simon

Megamyrmaecion perpusillum Simon

Tamopsis depressa Baehr and Baehr

Tamopsis occidentalis Baehr and Baehr

Holconia nigrigularis (Simon)

Heteropodidae

Olios calligaster (Thorell)

Heteropodidae

Asadipus banïwarn Platnick
Hersiliidae

Araneidae

Araneidae

Clubionidae

Clubionidae

Clubionidae

Desidae

Desidae

Gnaphosidae

Gnaphosidae

Hersiliidae

Lamponidae
Widespread and locally common in many parts of Australia, including the Shark Bay area (Waldock, 1991). Originally described from Queensland, this species was recorded from Dirk Hartog Island by Simon (1908).

Originally described from Dirk Hartog Island and North Fremantle, WA.

Originally described from Dirk Hartog Island, and not

subsequently recorded in the literature.

Known only from the type locality, Denham.

Originally described from the Swan River (Koch, 1873),

Simon (1909) recorded it from several localities, including

Dirk Hartog Island.

Known only from a single male collected $10 \mathrm{~km}$ ESE of Meedo Station Homestead

Known only from the type locality, Brown Station, Dirk Hartog Island.

Described from Denham and Moonyoonooka, WA, and not subsequently recorded in the literature

Described from Tamala and Wooroloo, WA, and not

subsequently recorded in the literature.

Known only from Badja Homestead and near Denham,

Western Australia, and central Northern Territory

Widespread in western Pilbara, extending as far south as Shark Bay

Originally recorded from Tamala and Northampton by

Simon (1908), Hirst (1991) found it to be widespread in the

semi-arid and arid regions of southern and central Australia

Originally described from eastern Australia, Simon (1908)

recorded it from Denham, Broome Hill, and possibly the

Murchison District.

Restricted to central W.A.
Carrollgouda Well

Shark Bay area.

Waldock (1991)

Brown Station, Dirk Hartog Island.

Simon (1908)

Brown Station, Dirk Hartog Island.

Brown Station, Dirk Hartog Island.

Denham

Brown Station, Dirk Hartog Island

Near Meedo Station Homestead

Simon (1908)

Simon (1908)

Simon (1909)

Simon (1909)

Main (1987)

The synonym $P$. tubicola was described from Denham by Simon (1908).

Dirk Hartog Island.

Simon (1908)

Simon (1908)

Denham

Simon (1908)

Tamala, Edel Land

Simon (1908)

A juvenile from near Denham was tentatively assigned to this species by Baehr and Baehr (1992)

Gascoyne River Crossing, near

Carnarvon

Recorded from Tamala Homestead by Simon (1909)

Denham

Baehr and Baehr

(1992, 1993)

Baehr and Baehr (1987, 1992, 1993)

Simon (1909), Hirst (1991)

Simon (1908)

Bidgemia Station, Boolathana Station, 


\section{Asadipus phaleratus (Simon)}

Lamponidae

Asadipus woodleigh Platnick

Bigenditia zuytdorp Platnick

Lampona cylindrata (L. Koch)

Lampona quinqueplagiata Simon

Lamponidae

Lamponidae

Lampona whaleback Platnick Lamponata daviesae Platnick Lamponella kimba Platnick Lamponina elongata Platnick
Originally described from several localities in W.A.; subsequently recorded from large areas of arid W.A., Qld and S.A.

Restricted to central W.A.

Widespread across arid Western and South Australia.

Widespread across southern Australia; accidentally introduced into New Zealand.

Described from Dirk Hartog Island and Boyanup, WA; subsequently recorded from numerous localities in central WA.

Known from Mt Whaleback and Bush Bay, WA Widespread across Australia.

Widespread in scattered localities across Australia. Widespread across southern arid Australia.

Widespread across arid Australia.
Bush Bay, Cape Cuvier Edel I and

Francois Peron National Park, Kennedy

Range, Mardathuna Station, Zuytdorp

Big Lagoon, Cape Cuvier, Edel Land,

Francois Peron National Park, Kennedy

Range, Mardathuna Station, Meedo

Station, Nanga Station, Nerren Nerren

Station, Zuytdorp

Bidgemia Station, Boolathana Station,

Bush Bay, Edel Land, Kennedy Range,

Mardathuna Station, Meedo Station,

Nanga Station, Woodleigh Station

Bidgemia Station, Boolathana Station,

Bush Bay, Kennedy Range, Mardathuna

Station, Nerren Nerren Station,

Woodleigh Station, Zuytdorp

Boolathana Station, Zuytdorp

Platnick (2000)

Platnick (2000)

Platnick (2000)

Brown Station, Dirk Hartog Island,

Boolathana Station, Bush Bay, Cape

Cuvier, Peron Peninsula, Edel Land,

Faure Island, Francois Peron National

Park, Kennedy Range, Mardathuna

Station, Monkey Mia, Nerren Nerren

Station, Woodleigh Station

Bush Bay

Tamala Station

Boolathana Station, Bush Bay

Francois Peron National Park, Bidgemi

Station, Boolathana Station, Bush Bay,

Cape Cuvier, Francois Peron National

Park, Kennedy Range, Mardathuna

Station, Meedo Station, Nanga Station,

Woodleigh Station

Bidgemia Station, Boolathana Station,

Cape Cuvier, Cape Lesueur, Peron

Peninsula, Edel Land, Faure Island,

Francois Peron National Park, Kennedy

Range, Mardathuna Station, Nanga

Station, Nerren Nerren Station,

Woodleigh Station, Zuytdorp 


\section{Notsodipus bidgemia Platnick}

Notsodipus quobba Platnick Pseudolampona boree Platnick

Lycosa mainae McKay (as L. maini) Lycosidae

Lycosa meracula Simon

Lycosidae

\section{Lycosa snelli McKay}

Miturga occidentalis Simon

Nicodamus mainae Harvey

Pholcus phalangioides (Fuesslin)

Ariadna thyrianthina Simon

Nephila edulis (Labillardiere) (as $N . \quad$ Tetragnathidae imperatrix L. Koch)

Dipoena (Lasaeola) austera Simon

Steatoda niveosignata (Simon) (as Lithyphantes niveo-signatus Simon) Bomis larvata L. Koch

Rebilus castaneus Simon

Storena sinuosa Jocqué and Baehr
Lycosidae

Miturgidae

Nicodamidae

Pholcidae

Segestriidae

\section{Theridiidae}

Theridiidae

Thomisidae

Trochanteriidae

Zodariidae

\section{Restricted to central W.A.}

Restricted to central coastal W.A.

Widespread across arid Australia.

Several localities throughout the Pilbara, Wheatbelt and

Goldfields regions

Originally described from Denham by Simon (1909),

McKay (1979) recorded this species from several near coastal localities in mid-western Australia. He also

dismissed Simon's (1909) record from Albany.

Found throughout the "Gascoyne, Ashburton and Pilbara regions" (McKay, 1975)

Originally described from four localities in WA, including

Tamala.

Widespread in southern WA and south-western South

Australia.

Simon (1908) recorded this cosmopolitan, synanthropic species from Denham and Geraldton, WA.

Described from four WA localities (Baba Head, Tamala, Norseman and Albany), this species has not been

subsequently reported in the literature.

This species is widespread in Australia, New Caledonia,

New Guinea and New Zealand (M. Harvey, unpublished

data).

Originally described from Denham, WA, and not

subsequently recorded in the literature.

Originally described from Denham and Eradu, WA, and

not subsequently recorded in the literature.

Originally described from eastern Australia, Simon (1908) Brown Station, Dirk Hartog Island

recorded it from Dirk Hartog Island.

Described from four WA localities (Tamala, Day Dawn,

Yalgoo and Mt Robinson near Kalgoorlie)

Widespread in Western Australia
Bidgemia Station, Nanga Station, Nerren

Nerren Station

Boolathana Station, Bush Bay, Edel

Land, Francois Peron National Park,

Kennedy Range, Mardathuna Station,

Meedo Station

Cape Cuvier

Francois Peron National Park, Zuytdorp

Billabong Roadhouse near Shark Bay

turnoff

Denham; Bernier Island; Carrarang

Station; Dorre Island

Platnick (2000)

Platnick (2000)

14.5 km S. of Carnarvon; near Manberry $\quad$ McKay (1975)

\section{Tamala, Edel Land}

Simon (1909)

Several localities, e.g. Carnarvon,

Hamelin Pool, Tamala Homestead

Denham

Harvey (1995)

Simon (1908)

Baba Head, Edel Land; Tamala, Edel

Land

Denham

Simon (1908)

Simon (1908)

Denham

Simon (1908)

Simon (1908)

Simon (1908)

Simon (1908)

Tamala, Edel Land

$35 \mathrm{~km}$ ENE of Yalardy
Jocqué and Baehr (1992) 
northern half of the Irwin District of the Southwestern Province, and the southern half of the Carnarvon District of the Eremaean Province (Beard, 1980). The vegetational characteristics are documented by Keighery et al. (2000), but briefly some of the southern survey sites support woodlands of Eucalyptus and Callitris, whereas the northern survey sites support Acacia shrublands to low open woodlands on fine textured soils and hummock grasslands on red sand surfaces. The demarcation between eucalypt woodlands and Acacia shrublands defines the boundary of the Southwest and the Eremaean Botanical Provinces (Beard, 1976, 1980, 1990), and is often referred to as the mulga-eucalypt line.

The physical environment of the Carnarvon Basin is outlined by Wyrwoll, Stoneman, Elliott and Sandercock (2000) and the climate by Wyrwoll, Courtney and Sandercock (2000). The climate in the southern half of the study area is semi-arid with temperate weather systems and an annual rainfall of c. $240-340 \mathrm{~mm}$. The central and northern areas are arid tropical although temperate systems affect its coastal areas in winter; the annual rainfall ranges from c. 200-240 mm (Wyrwoll, Courtney and Sandercock, 2000).

\section{Field Sampling}

The survey was based upon 63 quadrats distributed across 13 survey areas (Figure 1): Boolathana (BO), Bush Bay (BB), Cape Cuvier (CU), Edel Land (EL), Gascoyne Junction (GJ), Kennedy Range (KE), Mardathuna (MA), Meedo (MD), Nanga (NA), Nerren Nerren (NE), Peron Peninsula (PE), Woodleigh (WO) and Zuytdorp (ZU). At each survey area there were five quadrats, except for Cape Cuvier (six quadrats) and Edel Land (two quadrats). The quadrats were positioned to cover the geographical extent of the study area, represent the array of stratigraphic units present and provide some pseudoreplication of its main substrate types.

Sampling was conducted with the aid of two different types of pitfall traps: 'wet' traps and 'dry' traps.

Wet pitfall traps consisted of 25 litre buckets ( 300 $x 400 \mathrm{~mm}$ ) dug into the ground, with the top flush with the soil surface. Each was fitted with a lid into which five $10 \mathrm{~cm}$ diameter holes were cut. A piece of chicken wire (c. $1 \mathrm{~cm}$ mesh) was suspended several $\mathrm{cm}$ below the lid to allow any vertebrate which ventured into the trap to escape. This may have enabled larger invertebrates such as beetles and spiders to escape although a $2.5 \mathrm{~cm}$ gap was left between the wire and the wall of the bucket. Each trap was equipped with approximately 3.5 litres of preserving fluid ( 31 ethylene glycol, $40 \mathrm{ml}$ formalin, $350 \mathrm{ml}$ water). The traps were opened in August 1994, and the contents were cleared in September-October 1994, January 1995, May-June
1995, and in August 1995 when they were removed. Samples were returned to the laboratory, washed in water and stored in $75 \%$ ethyl alcohol until being sorted. Target organisms were removed, labelled and placed in separate vials or jars. Five wet pitfall traps were placed in each of the 63 quadrats, the total number of traps utilised being 315. Over the 12-month trapping period, we had the equivalent of some 115000 trap nights. The 12-month trapping period allowed for the full sampling of all seasons, and reduced the suspected bias that may occur in restricted sampling periods.

Live specimens were also removed from dry vertebrate pitfall traps (see McKenzie et al., 2000) in the same locations during each 5-day trapping program (September-October 1994, May-June 1995) and preserved in $75 \%$ ethyl alcohol.

Specimens were also hand collected during the field program, but to date we lack the resources to sort and label this material. All specimens were lodged in the Western Australian Museum, Perth.

\section{Data Analysis}

The data matrix (Table 2) comprised the presence and absence of species collected in both wet and dry pitfall traps at each quadrat, rather than their relative abundance. The latter technique was not adopted as there are few data available on the sampling bias in the use of pitfall traps (but see Churchill, 1999). The computer package PATN (Belbin, 1993) was used to explore the data matrix, exposing patterns in species composition. The Czekanowski association measure was used to compare the quadrats according to similarities in their species composition, and the 'Two-step' association measure was used to determine the quantitative relationship between each pair of species. The structure of the resulting association matrices was displayed as dendrograms using a modified 'unweighted pair group arithmetic averaging' (UPGMA) hierarchical clustering strategy (Sneath and Sokal, 1973), and the data matrix re-ordered accordingly, as a two-way table. The biological patterns revealed by these analyses were investigated in terms of a set of attributes related to the physical environments of the quadrats Wyrwoll, Stoneman, Elliott and Sandercock (2000), utilising the GSTA module in PATN, and assessed statistically with Kruskal-Wallis K-sample tests. Eleven climatic attributes were derived for each quadrat using ANUCLIM (McMahon et al., 1995). Soil and geomorphic attributes were also recorded from each quadrat (Wyrwoll, Stoneman, Elliott and Sandercock, 2000). The 17 soil chemical and texture values used herein were derived from sub-samples collected at a depth of $5-10 \mathrm{~cm}$ from $20-30$ regularly dispersed points on each quadrat, then bulked (Appendix D). Significant correlations between these physical attributes were identified 
using Kendall's rank correlation coefficient (Kendall's tau). Physical attribute names and codes are listed in Appendix 2.

\section{RESULTS}

Over 3600 vials of spiders containing more than 12000 specimens were sorted and identified during this survey, and the data are summarized in Table 2. A total of 33 families were represented which were classified into 146 genera and 285 species. As discussed below, time constraints precluded the identification of the Zodariidae and most of the Gnaphosidae which, if included, would probably increase the total number of species to over 350 (M. Harvey, unpublished data). Some of the species collected in the pitfall traps were clearly not part of the usual ground-dwelling fauna, and were most probably under-represented in the sampling regime utilised during this survey. Examples include webbuilding species such as Austracantha minax (Thorell) and Nephila edulis (Labillardière) which rarely descend out of their webs, and species which mostly reside on the surfaces of trees (e.g. species of Tamopsis). Nevertheless, these species are included in the matrix and were analysed as part of the total fauna.

Many taxa could not be assigned names, at either the generic or specific levels, a reflection of the deficiency in our taxonomic knowledge of spiders in Western Australia. It is possible that many of the species are undescribed, but the plethora of poorly known names in the scientific literature (such as Simon, 1908, 1909), combined with a lack of modern taxonomic revisions, hampers our understanding of these taxa, especially with regard to their biogeographic origins.

\section{The Spider Taxa}

\section{Araneidae}

Fifteen araneid species in eight genera were recorded (Table 2), including species which are known to be widespread outside of the study area, such as Argiope protensa L. Koch (Levi, 1983) and Austracantha minax (Thorell) (Waldock, 1991). Araneids spin orb-webs to capture prey and are generally poorly represented in pitfall catches, as they rarely venture on to the ground. Of particular interest was the large number of species of Dolophones, some represented by numerous adult male specimens from a variety of quadrats. Members of this orb-weaving spider genus generally remain in webs during the evening, and remove their web to take up a camouflaged position on a tree trunk or branch during the day. It would appear from the results presented here that male Dolophones disperse by travelling along the ground at least part of the time.

\section{Clubionidae}

Six species currently assigned to the Clubionidae were collected, including a species of Cheiracanthium and two species of Clubiona. Spiders of these genera are generally arboreal, and it is likely that they were under-represented in the pitfall trapping program.

The remaining three species are only doubtfully included in the Clubionidae, and their systematic status is currently under revision (R.J. Raven, pers. comm.). A single species of Fissarena was taken from three quadrats (BO5, CU4, CU5), belonging to a genus which has only recently been described from the Simpson Desert, south-western Queensland (Henschel et al., 1995). Two species of Meedo were collected, including Meedo houstoni Main from 15 northern quadrats, and an undescribed species, M. sp. 1, from three southern quadrats (Table 2). The former species was previously only known from the holotype collected near Meedo Homestead (Main, 1987), and is now known to be widespread throughout the study area north of the mulgaeucalypt line, whereas the undescribed species is restricted to the south-western portion of the study area.

\section{Corinnidae}

Seven corinnid species, tentatively placed within six genera, were collected. Genus 5, sp. 1 was taken at only a single quadrat, but the others were more widespread (Table 2). Corinnids are groundhunting spiders.

\section{Cyatholipidae}

Three undescribed species of the Australian endemic genus Matilda were collected, M. sp. 1 at three quadrats, $M$. sp. 2 at one quadrat and $M$. sp. 3 at one quadrat (Table 2). These are all small spiders and may be under-represented in the study due to their lack of mobility.

\section{Deinopidae}

A single species of Deinopis was collected across five northern coastal quadrats. Deinopids cast unique catching webs, often close to the ground, with which they seize prey.

\section{Desidae}

Six species attributed to the Desidae were collected, including Badumna insignis (Thorell), a species known to be widespread across much of Australia, and five further species attributed to different putative genera. Some desids are often found on the bark of trees or logs, but many others spin small webs near to the ground.

\section{Dictynidae}

Three dictynids, tentatively assigned to separate genera, were recorded, but only Genus 2, sp. 1 was 
Table 2 The frequency of occurrence across quadrats of all araneomorph spiders (except Gnaphosidae and Zodariidae) collected in both wet and dry pitfall traps for each of the 13 survey areas (see text for explanation of abbreviations). There were five quadrats at each survey area, except for CU which had six, and EL which had two.

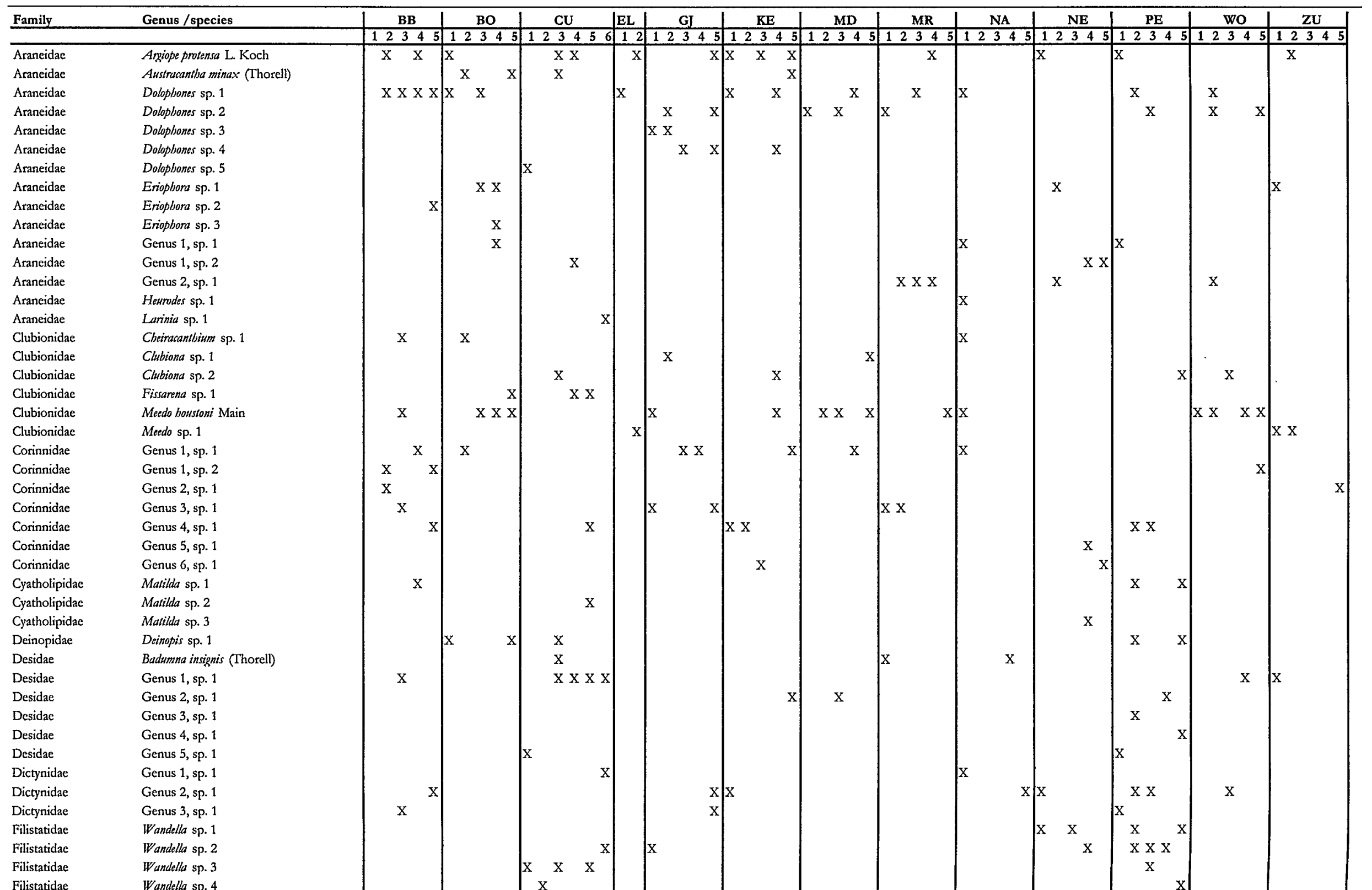


memicloea sp. 2

Gnaphosidae

emicloea sp. 3

Hersiliidac

Hersiliidae

Heteropodidac

Hemicloea sp. 4

Hemicloea sp. 5

Tamopsis octidentalis Baehr and Bachr Tamapsis sp. 1

Tamop.sis sp. 2

Heteropodida

Hopoda kalbarri Todd Davics

Heteropodidac Honis nigularis (Simon)

Heteropodida

Isopedella saunderri ( $(\mathrm{Hogg})$

Heteropodidac

Nea.sparassus sp. 1

Heteropodidac

Neosparassus sp. 2

Heteropodidae

Heteropodidae

Heteropodidac

Heteropodidac

Heteropodidae

Heteropodidae

Lamponidae

Neosparassus sp. 3

Neosparassus sp. 4

Neo.sparassur sp. 5

us sp.

Neosparassus sp. 7

Neosparassus sp. 8

Neosparassus sp. 9

Pediana tenuis Hogg

Genus 1, sp. 1

Lamponidac

Lampona cylindrata (L. Koch)

Linyphiidac

Linyphiidac

Linyphiidae

Linyphiidae

Liocranidae

Liocranidae

Locranidae

Lycosidac

Lycosidae

Lycosidae

Lycosidae

Lycosidae

Lycosidae

Lycosidac

Lycosidae

Lycosidae

Lycosidae

Lycosidae

Lycosidae

Lycosidac

Lycosidae

Erigone sp. 1

Genus 1, sp. 1

Genus 2, sp. 1

Genus 3, sp. 1

Orthobula sp. 1

Orlisobula sp. 2

Ortiobula sp. 3

Genus 1, sp. 1

Genus 2, sp. 1

Genus 2, sp. 2

Genus 3, sp. 1

Genus 4, sp. 1

Genus 5, sp. 1

Lycosa bicolor Hoge

Lycosa bicolor Hogg

Lycosa foresi McKay

Lycosa mainae McKay

Lycosa sp. 01

Lycosa sp. 02

Lycosa sp. 03

Lycosa sp. 04

Lycosidae

Lycosa sp. 05

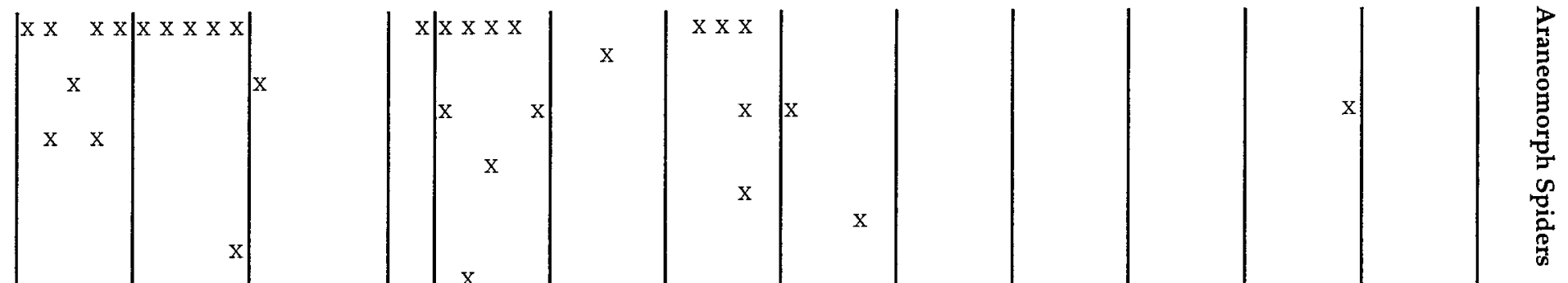

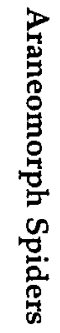

$\mathrm{X}$
$\mathrm{X}$

$\mathrm{x}$

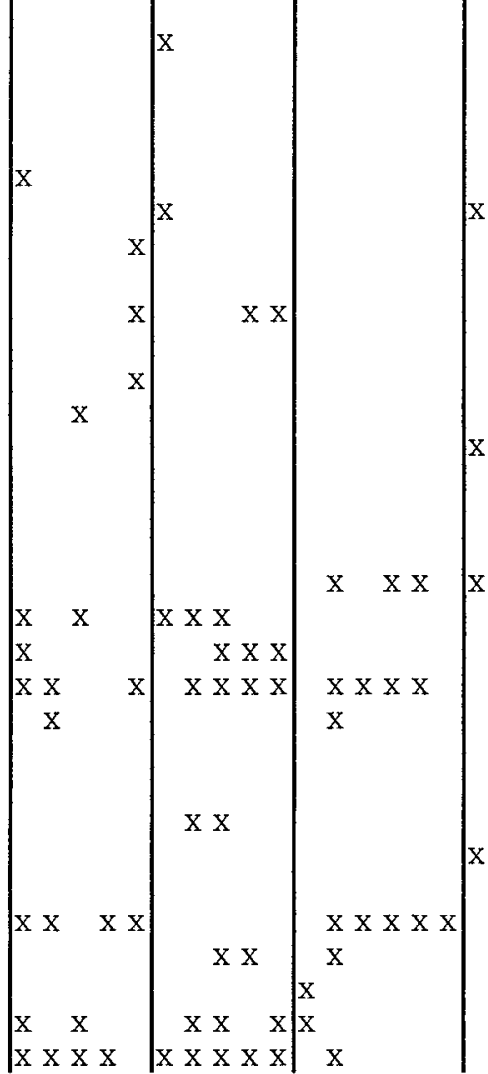

$\mathrm{x}$

$x$

$x \mid \begin{array}{llll}x \times x & x & x & x\end{array}$

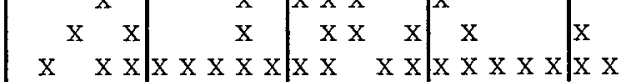

$\mathrm{x}$ $\mathrm{x}$

$\mathrm{x}$

$\mathrm{x}$

$\mathrm{x}$

$\mathrm{x}$

$\begin{array}{lll}x & x \times x & x \times x\end{array}$

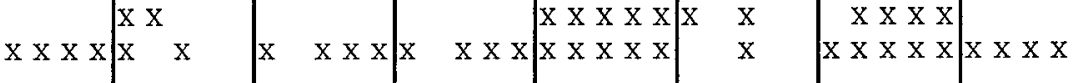

$\mathrm{X}$

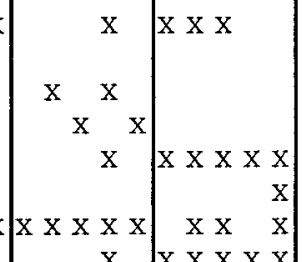




\begin{tabular}{|c|c|c|c|c|c|c|c|c|c|c|c|c|c|c|}
\hline Family & Genus /species & $\mid$\begin{tabular}{|c|}
$\mathrm{BB}$ \\
12345
\end{tabular} & $\mid \frac{\text { BO }}{12345}$ & $\frac{\mathrm{CU}}{123456}$ & $\mid$\begin{tabular}{|l|} 
EL \\
12
\end{tabular} & $\frac{G J}{12345}$ & $\mid \frac{\mathrm{KE}}{12345}$ & \begin{tabular}{|c|} 
MD \\
12345
\end{tabular} & \begin{tabular}{c|} 
MR \\
12345
\end{tabular} & $\mid \frac{N A}{\mid 12345}$ & $\frac{N E}{12345}$ & \begin{tabular}{c|}
$\mathrm{PE}$ \\
12345
\end{tabular} & \begin{tabular}{|c|} 
wo \\
123445
\end{tabular} & $\mid \frac{z U}{12345}$ \\
\hline Lycosidae & Lycosa sp. 06 & & & & & & & & & & & $\mathrm{x} \times \mathrm{x} \times$ & & $\mathrm{x}$ \\
\hline Lycosidae & Lycosa sp. 07 & $\mathrm{x} \times \mathrm{x}$ & $\mathrm{x}$ & $\mathrm{x}$ & & & & & $\mathrm{x}$ & $\mathrm{x} \quad \mathrm{x}$ & & $\mathrm{x} \times \mathrm{x}$ & & $\mathrm{x} \times \mathrm{xx}$ \\
\hline Lycosidae & Lycosa sp. 08 & & $\left|\begin{array}{llll}x & \mathrm{x} & \mathrm{x} & \mathrm{x}\end{array}\right|$ & & & $\mathrm{x}$ & & & & $\mathrm{x} \times \mathrm{x}$ & $\mathrm{x}$ & $\mathrm{x} \times \mathrm{x}$ & $\mathrm{x} \quad \mathrm{x}$ & \\
\hline Lycosidae & Lycosa sp. 09 & $\mathrm{x}$ & $\mathrm{x} \times \mathrm{x} \times \mathrm{x}$ & & & $\mathrm{x}$ & & & $\mathrm{x}$ & & & & $\mathrm{x}$ & \\
\hline Lycosidae & Lyrosa sp. 10 & & $\mathrm{xx}$ & $\mathrm{x} x$ & & & & $\mathrm{x}$ & $\mathrm{x}$ & $\mathrm{xx}$ & $\mathrm{x}$ & $\mathrm{x}$ & $\mathrm{x}$ & $\mathrm{x} \times \mathrm{x} \times \mathrm{x} x$ \\
\hline Lycosidae & Lyoosa sp. 11 & & $\mathrm{x} \quad \mathrm{x}$ & & & & $\mathrm{x}$ & $\mathrm{x} x$ & $\mathrm{x} \times \mathrm{x}$ & $\mathrm{x} \times \mathrm{x} \times$ & $\mathrm{x} \times \mathrm{x}$ & $\mathrm{x} x \quad \mathrm{x}$ & & \\
\hline Lycosidae & Lycosa sp. 12 & $\mathrm{x} \mathrm{x}$ & & & $\mathrm{x}$ & $\mathrm{x}$ & & & & & $\mathrm{x} \times \mathrm{x} x$ & $\mathrm{x} x \quad \mathrm{x}$ & & $\mathrm{x} \times \mathrm{x} \times \mathrm{x}$ \\
\hline Lycosidae & Lycosa sp. 13 & $\mathrm{x}$ & $\mathrm{x} \times \mathrm{x}$ & & & $\mathrm{x}$ & & $\begin{array}{ll}x & x\end{array}$ & & $\mathrm{x} \quad \mathrm{x}$ & $\mathrm{x}$ & $\mathrm{x}$ & $\mathrm{xx}$ & $\mathrm{x} \times \mathrm{xx}$ \\
\hline Lycosidae & Lycosa sp. 14 & $\mathrm{x}$ & $\mathrm{x}$ & $\mathrm{x} \times$ & $\mathrm{x}$ & $\mathrm{x}$ & & $\mathrm{x}$ & & $x \times x \times$ & $\mathrm{x}$ & $\mathrm{x} \times \mathrm{x}$ & $\mathrm{x}$ & 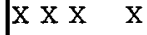 \\
\hline Lycosidae & Lycosa sp. 15 & & & & & & & & & $\mathrm{x}$ & $\mathrm{x} \times \mathrm{x}$ & & $\mathrm{x}$ & \\
\hline Lycosidae & Lycosa sp. 16 & $\mathrm{x}$ & $\mathrm{x}$ & & & $\mathrm{x}$ & & & $\mathrm{x}$ & $\mathrm{x}$ & & & $\left|\begin{array}{lll}x & x & x\end{array}\right|$ & \\
\hline Lycosidae & Lyorasa sp. 17 & $\mathrm{x}$ & & $\mathrm{xx}$ & & $\mathrm{x}$ & $\mathrm{x}$ & $\mathrm{x}$ & $\mathrm{x}$ & $\mathrm{x}$ & $\mathrm{x} \times \mathrm{x}$ & & $\left|\begin{array}{ll}x & x\end{array}\right|$ & $\mathrm{x}$ \\
\hline Lycosidae & Lycosa sp. 18 & $\mathrm{x}$ & $x$ & $\mathrm{x}$ & & $\mathrm{x}$ & $\mathrm{x} \mathrm{x}$ & & $\mathrm{x}$ & & & & $x \times$ & \\
\hline Lycosidae & Lycosa sp. 19 & & & & & $\mathrm{x} \quad \mathrm{x}$ & & & $\mathrm{x} x$ & & & & $\mathrm{x}$ & \\
\hline Lycosidae & Lycosa sp. 20 & $\mathrm{x} x$ & $\mathrm{x}$ & $\mathrm{xx}$ & & & & $\mathrm{x}$ & $\mathrm{x}$ & & & & $\mathrm{x}$ & \\
\hline Lycosidae & Lycosa sp. 21 & & & $\mathrm{x}$ & $|\mathrm{x} x|$ & & & & & $\mathrm{x}$ & $\mathrm{x}$ & $\mathrm{x}$ & & \\
\hline Lycosidae & Lyyosa sp. 22 & $\mathrm{x}$ & & $\mathrm{x} \times \mathrm{x} \quad \mathrm{x}$ & & & & & & & & $\mathrm{x}$ & & \\
\hline Lycosidae & Lycosa sp. 23 & $\mathrm{x}$ & & & & & & & & $\mathrm{x}$ & $\mathrm{x}$ & & & \\
\hline Lycosidae & Lycosa sp. 24 & & & & & $\mathrm{x}$ & & & & & & & & \\
\hline Lycosidae & Lycosa sp. 25 & & & $\mathrm{x}$ & & & & & & & & & & \\
\hline Micropholcommatidae & Genus 1, sp. 1 & & & & & & & & & & & & & $\mathrm{x}$ \\
\hline Miturgidae & Genus 1, sp. 1 & $\mathrm{x}$ & $\mathrm{x} \times \mathrm{x}$ & & & $\mathrm{x}$ & $\mathrm{x} \times \mathrm{x}$ & $\mathrm{x} \times \mathrm{x}$ & & & & & & \\
\hline Miturgidae & Genus 1, sp. 2 & & & & & & & & & $\mathrm{x} \quad \mathrm{x} x$ & $\mathrm{X} \times \mathrm{x} \times \mathrm{X}$ & $\mathrm{x} \times \mathrm{x}$ & $\mathrm{X} \times \mathrm{x}$ & \\
\hline Miturgidae & Genus 2, sp. 1 & & & X X X X & & & & & $\mathrm{x} \times \mathrm{x} \times$ & $\mathrm{x} \times \mathrm{x}$ & $\mathrm{x}$ & & $\mathrm{x}$ & $\mathrm{x} \times \mathrm{x} x$ \\
\hline Miturgidae & Genus 2, sp. 2 & $\mathrm{x}$ & $\mathrm{x}$ & $\mathrm{x} \quad \mathrm{x}$ & & $\mathrm{x} x$ & & $\mathrm{x}$ & $\times \times \times x$ & $\mathrm{x}$ & & $\mathrm{x}$ & $\mathrm{x}$ & \\
\hline Miturgidae & Genus 2, sp. 3 & & & & $|\mathrm{x} x|$ & & & & & & & & & $\mathrm{x} x$ \\
\hline Miturgidae & Genus 2, sp. 4 & & & $\mathrm{xx} \quad \mathrm{x}$ & & & & & $x \times x$ & & & & & \\
\hline Miturgidae & Genus 2, sp. 5 & & $\mathrm{xx}$ & & & & & & & & & & & \\
\hline Miturgidae & Genus 2, sp. 6 & $\mathrm{x}$ & $\left|\begin{array}{lllll}x & x & x & x & x\end{array}\right|$ & & & $\mathrm{x} \times \mathrm{x} \times \mathrm{x}$ & $\mathrm{x} \times \mathrm{x}$ & $\mathrm{x} \times \mathrm{x} \times \mathrm{x}$ & $\left|\begin{array}{lll}x & x & x\end{array}\right|$ & $\mathrm{X}$ & & & $\mid \begin{array}{llll}x & X & X & X \\
x\end{array}$ & \\
\hline Miturgidae & Genus 3, sp. 1 & & & & & $\mathrm{xx}$ & $\mathrm{xxx}$ & $\mathrm{x} \quad \mathrm{x} \times \mathrm{x}$ & $\mathrm{xx}$ & & $\mathrm{x}$ & & 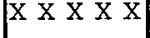 & \\
\hline Miturgidae & Genus 4, sp. 1 & & & & & & & & & & & & & $\mathrm{x}$ \\
\hline Miturgidae & Miturya agelenina (Simon) & $\mathrm{x} \quad \mathrm{x}$ & & & & & & & & & & & & $\mathrm{x} \mathrm{X}$ \\
\hline Miturgidae & Miturya sp. 1 & X X X & $\mathrm{x} \times \mathrm{x}$ & & & $\mathrm{x}$ & $\mathrm{x} \times \mathrm{x}$ & $\mathrm{x} \times \mathrm{x}$ & 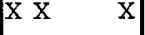 & \begin{tabular}{l|l}
$x$ & -1
\end{tabular} & & $\mathrm{x}$ & $\mathrm{x}$ & \\
\hline Miturgidae & Miturna sp. 2 & $x \quad x \quad x \quad x$ & $\mathrm{x}$ & $\mathrm{x} \times \mathrm{x} \times \mathrm{x}$ & & & $\mathrm{x} \quad \mathrm{x}$ & & $\mid \mathrm{x} \times \mathrm{x} x$ & $x \times x$ & $\mathrm{x} \times \mathrm{x}$ & $\mathrm{x}$ & $\mid \mathrm{x} \times \mathrm{x} x$ & $\mathrm{x}$ \\
\hline Miturgidae & Miturna sp. 3 & $\mathrm{x}$ & & & & & $\mathrm{x} \times \mathrm{x}$ & & $\mathrm{x}$ & & & & & \\
\hline Miturgidae & Miturga sp. 4 & & & & & & & & & & & & & $\int^{X} \ldots$ \\
\hline Miturgidae & Uliodon tarantulinus (L. Koch) & $\mathrm{x}$ & & $\mathrm{x}$ & & & $\mathrm{x}$ & & & $\mathrm{x}$ & & & & $\mathrm{XXXX}$ \\
\hline Nicodamidae & Nicodamus mainat Harvey & $\mathrm{x} \quad \mathrm{x} \times \mathrm{x}$ & $\mathrm{x}$ & & & & $\mathrm{x}$ & & & $\begin{array}{lll}x & x & x\end{array}$ & $\mathrm{x}$ & $\mathrm{x}$ & & \\
\hline Oonopidac & Gamasomorpba sp. 1 & $\mathrm{x} x$ & & $\mathrm{x} x$ & & & $\mathrm{x} \times$ & & & $x \quad x$ & & & $\mathrm{x}$ & $\mathrm{x} x$ \\
\hline Oonopidae & Gamasomorpbasp. 2 & & $\mathrm{x} x$ & & & & & & & & & $\mathrm{x}$ & $\mathrm{X}$ & \\
\hline Oonopidae & Genus 1, sp. 1 & & 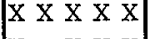 & & & & & & $\mathrm{x}$ & & & & $\mathrm{x}$ & $\mathrm{x}$ \\
\hline Oonopidae & Gyymexs sp. 1 & $\mathrm{x}$ & 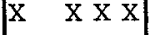 & & & $\mathrm{x}$ & $\mathrm{x}$ & $\mathrm{xx}$ & & $x \times x \times$ & $\mathrm{x}$ & $\mathrm{xx}$ & $\mathrm{x} \times \mathrm{x}$ & $\mathrm{x} \times \mathrm{x}$ \\
\hline Oonopidae & Gymeus sp. 2 & $\mathrm{x}$ & $\mathrm{x}$ & & & & $\mathrm{x}$ & $\mathrm{x}$ & & & & & & \\
\hline Oonopidae & Gymeus sp. 3 & & & & & & & & & & & $\mathrm{x}$ & & $\mathrm{xx}$ \\
\hline Oonopidae & Gyymeus sp. 4 & $\mathrm{x}$ & & & & $\mathrm{x}$ & & $\mathrm{x}$ & & & & $\mathrm{x}$ & $\mathrm{x}$ & \\
\hline
\end{tabular}




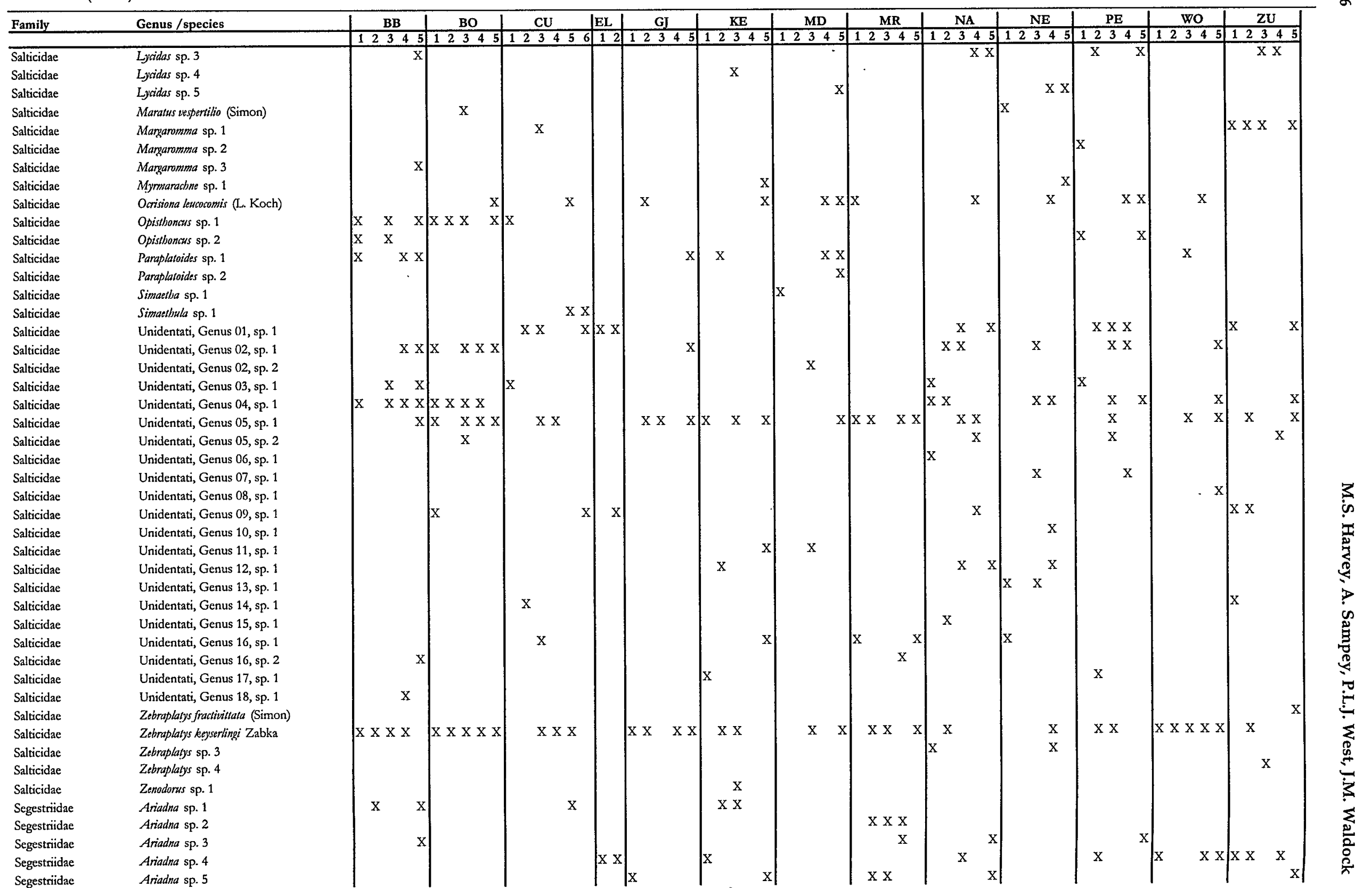


found at more than three quadrats. Dicytnids occur in various habitats, including on the ground and in foliage.

\section{Filistatidae}

The Filistatidae were represented by five undescribed species of Wandella, many of which were taken from several survey areas widely scattered across the study area. A recent revision of the family (Gray, 1994) showed that the Australian Filistatidae are taxonomically diverse at the species level. Filistatids often occur under bark, but many roam across the ground in search of prey and mates.

\section{Gallieniellidae}

Two species of this highly restricted and littleknown family were recorded from the study area, Genus 1, sp. 1 at KE3 and Genus 1, sp. 2 at BB3 and CU1. Gallieniellids are hunting spiders found close to the ground.

\section{Gnaphosidae}

Preliminary sorting indicated that the Gnaphosidae represented one of the most diverse spider families in the survey. Time constraints precluded species-level identifications, apart from members of the Hemicloeinae for which five species of Hemicloea were collected from very few localities, possibly reflecting their corticolous nature. Other gnaphosids are also bark-dwelling, but many others are found at ground-level under leaf litter and amongst rocks.

\section{Hersiliidae}

Hersiliids are tree-dwelling spiders, which rarely fall into pitfall traps. Tamopsis occidentalis Baehr and Baehr was recorded from BO5, while Tamopsis sp. 1 and Tamopsis sp. 2 were taken at one (GJ2) and two (MD5, MR2) quadrats, respectively.

\section{Heteropodidae}

Fourteen species of Heteropodidae were collected, including single species of Delena, Heteropoda, Holconia, Isopodella and Pediana, of which the most abundant were Heteropoda kalbarri Todd Davies (9 quadrats) and Pediana tenuis Hogg (7 quadrats) which have been previously recorded from the study area or from nearby areas (Davies, 1994; Hirst, 1989). Nine species of Neosparassus were collected, but most were from just a few quadrats. Heteropodids usually dwell amongst foliage or under tree bark, but many move across the ground to find new habitat.

\section{Lamponidae}

The ground and bark dwelling members of the Lamponidae were well represented in the survey, with 15 species being recorded by Platnick (2000).
However, not all records have yet been collated from this revision, and we are able to present data on only two species. Lampona cylindrata (L. Koch), which is widespread throughout southern Australia, was found at four quadrats, and Pseudolampona boree Platnick, which was found at PE5 and ZU3. Elsewhere this species is found in other parts of southern Australia (Platnick, 2000).

\section{Linyphiidae}

Four species of Linyphiidae were taken, including a species of Erigone. However, each species was represented by very few specimens and due to their habit of spinning small sheet-webs, may be underrepresented in the survey.

\section{Liocranidae}

Three species of Orthobula were each collected at a single quadrat (ZU3, MR5 and NE4). These small spiders are generally found in leaf litter.

\section{Lycosidae}

Numerous members of the ground-hunting family Lycosidae, wolf spiders, were frequently recorded during the survey, and 35 species were detected, of which three could be assigned to previously described species. Lycosa bicolor Hogg was recorded from 11 quadrats, which extends the known range of the species further to the west (McKay, 1973). Lycosa forresti McKay was collected at two quadrats in the southern portion of the survey area (EL1 and NA4), which is in accordance with the known distribution of the species, which is generally to the south-east of the study area (McKay, 1973). Lycosa mainae McKay was collected at two quadrats on Peron Peninsula (PE2 and PE4), extending the known range of the species further to the north-west (McKay, 1979). However, the distribution of L. mainae was found to be greater, as specimens were hand-collected from burrows at Nerren Nerren Station, even though no specimens were collected by pitfall trapping in the area.

Genus 1, sp. 1 and Lycosa sp. 1 were recorded mainly from coastal localities (BB, CU, EL, PE and $\mathrm{ZU})$. The two species of Genus 2 were quite widespread, whereas the three species attributed to Genera 3, 4 and 5 were quite localised. The remaining species of $L y \cos a$ were variably distributed, with many species widespread throughout the study area, and others more restricted.

\section{Micropholcommatidae}

A single specimen of the Gondwanan family Micropholcommatidae was collected at ZU3, probably representing the northern limit of the family in Western Australia ( $M$ : Harvey, 
unpublished data). These tiny litter-dwelling spiders are rarely found in pitfall traps.

\section{Miturgidae}

Sixteen species in six genera were collected, of which the most abundant were Genus 1, spp. 1 and 2, and Genus 2, sp. 6, and two species of Miturga (spp. 1 and 2). Uliodon tarantulinus (L. Koch), which is widespread across Australia ( $R$. Raven, in litt.), was found at eight quadrats. Miturgids spin silken retreats under rocks and logs, but venture out to hunt and mate.

\section{Nicodamidae}

The sole species of Nicodamidae previously known from the study area, Nicodamus mainae Harvey, was taken from 12 quadrats from a total of 6 survey areas (BB, BO, KE, NA, NE and PE) scattered throughout the study area. Nicodamus mainae is widespread throughout the southern half of Western Australia, occupying a wide variety of dry habitats (Harvey, 1995). Nicodamids spin undifferentiated webs under rocks and logs, but males wander in search of females during the mating season, often during daylight hours.

\section{Oonopidae}

The tiny litter-dwelling spiders which constitute the family Oonopidae were well represented in the survey, and 15 species in six genera were collected, including two species of Gamasomorpha, a single species of Orchestina, and four species of Opopaea. The genus Myrmopopaea was extremely common and widespread, and despite the presence of morphological variation between specimens, it was not possible to satisfactorily assign species-level rank to these variants. Therefore, for the purposes of this study, we recognise only a single species of Myrmopopaea. The genus Grymeus was found to consist of six species of which G. sp. 1 and G. sp. 6 were the most widespread. A single species of an undescribed genus (Genus 1, sp. 1) was recorded at eight quadrats.

\section{Oxyopidae}

Distinguishing between the various species of Oxyopes found in the survey was difficult, and we were only able to confidently identify two species. The remaining specimens have not been identified to species level, and were excluded from the analysis. Oxyopids are common inhabitants of grasses and low shrubland, where they will sit and attempt to catch prey.

\section{Pholcidae}

The Pholcidae were represented by two species of Trichocyclus, one of which ( $T$. sp. 1 ) was found at numerous quadrats, while the other ( $T$. sp. 2) was restricted to KE3. These spiders spin undifferentiated webs, but males often wander in search of females during mating season.

\section{Prodidomidae}

The Prodidomidae were found to be particularly diverse in the study area, with 20 species in eight genera collected. Prodidomids are ground-hunting spiders and some, such as the molycriines, specialise by preying on ants.

The Prodidominae consisted of three species of Prodidomus and three species belonging to two different, possibly undescribed, genera. Prodidomus sp. 1 was found to be very widespread, while $P$. sp. 2, P. sp. 3 and Genus 2, sp. 2 were only found at single quadrats at GJ1, BO3 and ZU3, respectively. Genus 1, sp. 1 and Genus 2, sp. 1 were found at three quadrats across mutually exclusive survey areas.

The Molycriinae were represented by eight species, of which the three species included in Genus 1 were significantly larger than the others. Genus 2, sp. 1 was extremely widespread, and was found at all survey areas with the exception of $\mathrm{CU}$ and ZU. In contrast, Genus 2, sp. 2 was only found at CU, and Genus 2, sp. 3 only at BO. Genus 3, sp. 1 was also widespread, but Genus 4, sp. 1 was restricted to $\mathrm{BO}$ and $\mathrm{GJ}$.

Six species of the little-known genus Cryptoerithus were recognized, of which most were relatively widespread. The subfamilial placement of this genus is currently uncertain (V. Ovtsharenko, personal communication).

\section{Salticidae}

The Salticidae represented the most diverse family currently analysed from the survey with 58 species placed in 39 genera. They are found in a variety of terrestrial habitats, including under bark, under rocks, amongst leaf litter or on low vegetation.

Three species of Grayenulla were recorded, of which Grayenulla australensis Żabka, previously known from the Goldfields region of Western Australia (Źabka, 1992a), was found to be widespread throughout the survey area, absent only from Edel Land. Two undescribed species of Grayenulla were collected at only one or two northern survey areas.

Two species of Holoplatys were collected, $H$. planissima sp. group at $\mathrm{KE}, \mathrm{PE}$ and $\mathrm{WO}$, and the other, H. sp. 2, at a single southern quadrat (ZU). Holoplatys is an extremely diverse genus which is widespread in Australia, New Caledonia and New Zealand (Żabka, 1991).

Maratus vespertilio (Simon) was found at two quadrats on $\mathrm{BO}$ and $\mathrm{NE}$; it has also been found in other parts of southern Australia (J. Waldock, unpublished data). 
Ocrisiona leucocomis (L.Koch) was found at 12 quadrats, representing the first specimens recorded north of Perth. The species is widespread throughout eastern and southern Australia (Zabka, 1990).

Two species of the genus Paraplatoides were recorded, one at eight quadrats $(P . \mathrm{sp} .1)$ and the other at one quadrat ( $P . s p .2)$. This is the first record of the genus from outside eastern Australia (Zabka, 1992a).

The endemic Australian genus Zebraplatys was represented by four species, Z. fractivittata (Simon), $Z$. keyserlingi Żabka and two undescribed species. Zebraplatys fractivittata was collected once at ZU5, extending its known distribution further north (Żabka, 1992b), while Z. keyserlingi, previously known from only the male holotype from Woodstock Station in the northern Pilbara (Zabka, 1992b), was found to be widespread throughout the survey area at 33 quadrats. Two undescribed species of Zebraplatys were found at NA1, NE4 (Z. sp. 3) and ZU3 (Z. sp. 4).

Little can be said of the remaining salticid species, presumably undescribed, detected in the survey, but many taxa were recorded from few quadrats, indicating that they are either rarely collected in pitfall traps or that there is significant local endemism.

\section{Segestriidae}

Seven species of Ariadna were discerned, of which A. sp. 7 was the most abundant, being found at 36 quadrats. Segestriids dig burrows into the soil, into tree bark, or between rock fissures, but males roam in search of females during the mating season.

\section{Selenopidae}

Only a single species of Selenops was taken at BB3. It is unlikely that pitfall trapping would adequately sample for selenopids, as they are mostly restricted to the underside of stones and rocks, and are rarely found outside of this habitat.

\section{Stiphidiidae}

A single species of Corasoides was taken at three quadrats (NA1, NE5 and PE3), and three species of Forsterina of which F. sp. 1 was widespread across the study area. Six species, placed in putatively separate genera, were collected at a few quadrats. Stiphidiids spin webs, ranging from poorly differentiated structures in Forsterina to elaborate sheet webs in Corasoides.

\section{Tetragnathidae}

A single female specimen of Nephila edulis (Labillardière) was collected in a pitfall trap at NE1. These web-building spiders are abundant throughout the study area, as well as elsewhere in
Australia, New Caledonia, New Guinea and New Zealand (M. Harvey, unpublished data). Similarly, the only other tetragnathid collected, Genus 1, sp. 1, was represented by a single male from WO5.

\section{Theridiidae}

Fifteen species of Theridiidae attributable to 10 genera were collected, including four species of Steatoda (16, 6, 3 and 4 quadrats, respectively), Latrodectus hasseltii Thorell (8 quadrats), a single species of Enoplognatha (2 quadrats, CU1, PE1) and single species representing three unidentified genera $(7,1$ and 2 quadrats, respectively). The Hadrotarsinae were represented by two species of Euryopis (12 and 9 quadrats, respectively), three species of Gmogala (4, 3 and 2 quadrats, respectively) and a single species of Trigonobothrys (1 quadrat, NE4). As part of a recent revision of the genus Gmogala (M. Harvey and J. Waldock, unpublished data), Gmogala sp. 1 was found throughout Western Australia and South Australia, Gmogala sp. 2 was not found outside of the study area, and Gmogala sp. 3 was found to be extremely widespread throughout southern Australia. Theridiids generally spin tangle webs and are not particularly amenable to capture in pitfall traps, but the hadrotarsines occur in leaf litter and at the bases of low vegetation, thus making them more susceptible to capture.

\section{Thomisidae}

Only two genera of Thomidae were recorded: Stephanopis with seven species and Tharpyna with three species. Both genera are generally found under the bark of trees, particularly eucalypts.

\section{Trochanteriidae}

Seven species of the Gondwanan family Trochanteriidae were collected, mostly represented by adult males presumably moving about on the ground in search of mates.

\section{Zodariidae}

Preliminary sorting indicated that the Zodariidae were extremely diverse in the study area, but time constraints precluded species-level identifications.

\section{Zoridae}

Three zorids were found in the study area: single species of Argoctenus, Hestimodema and Thasyraea. The latter two genera were very rarely collected, whilst Argoctenus sp. 1 was found at most survey areas. Zorids are ground-hunting spiders.

\section{Species Richness and Assemblage Composition}

We identified 285 species across the 63 quadrats, ranging from 12 to 56 species per quadrat. Species richness was generally poorest on quadrats situated 
on saline claypans (PE1 with 12 species, CU1 with 14 species and NA1 with 28 species), but at BB3, another saline claypan, 44 species were recorded. Other depauperate quadrats included the two Edel Land quadrats which were situated on fine calcareous dunes, with 14 and 16 species, respectively. The five richest quadrats were $\mathrm{BO} 3-5$ and PE2-3 with 49-56 species each, all situated in Acacia shrubland. The overall species richness was little affected by regular grazing by introduced herbivores (e.g. stock, feral goats and/or rabbits), and even the quadrats with obvious sheet erosion, minimal leaf litter, and/or no A1 soil-horizon, retained high species richness [e.g. BO5 (52 species), GJ4-5 (25, 35), KE4 (36), MD1-2, 4-5 (22, 20, 33, 34), PE4 (43) and WO1 (33)].

In Table 3 the data have been re-ordered according to the quadrat and species classification analyses.

When the 63 quadrats were classified according to similarities in their species composition (Figure 2), five dendrogram partitions were recognisable in terms of their geographical location and substrate type. Analysis confirmed significant differences in various climatic and substrate attributes: 'annual average precipitation' (Pann), 'soil potassium' [K(HCO3)], 'soil exchangeable magnesium' (exMg) and 'exchangeable sodium' (exNa) provided the best statistical separation of the five groups defined in Figure 2 (Figure 3), although Pann and $\mathrm{K}(\mathrm{HCO} 3)$ were tightly inter-correlated $\left(R^{2}=-0.43, p<0.0001\right)$, as were exMg and exNa $\left(\mathrm{R}^{2}=0.52, \mathrm{p}<0.0001\right)$. When the dendrogram clusters at the 17-group level were examined, we noted that many of the groups comprised quadrats from a single survey area (Table 3). In contrast, the structure of the dendrogram derived from the species classification was the only basis used to partition the 285 species in the data matrix into 30 assemblages; unfortunately, detailed ecological data on the grounddwelling spiders of the region are too scant to provide an extrinsic rationale for this partitioning decision.

Three distinct types of species assemblage were apparent in Table 3. Two were related to ecological or biogeographical gradients, and one to the

\section{Group Levels}

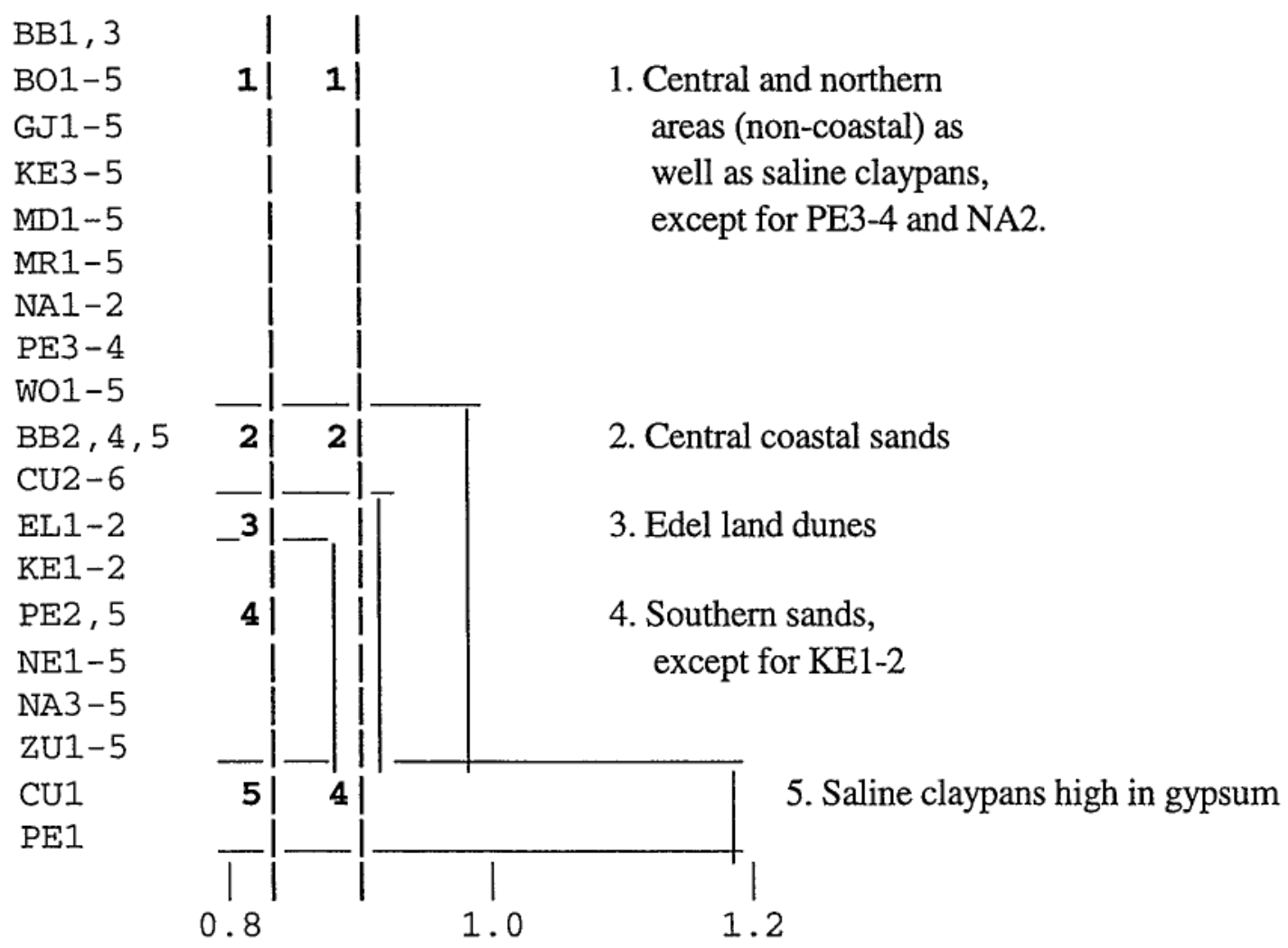

\section{Coefficient of dis-similarity}

Figure 2 Quadrats classified according to similarities in their species composition. Dendrogram structure is displayed to the 8-group level, and cut at the 4- and 5-group levels. 
strongly localised patterns of occurrence in their component species.

1. Species assemblages 1 to 4 comprised species that were widespread in the study area;

2. Assemblages 5 to 27 and assemblage 30 comprised species with strongly localised distributions in the study area. Their component species were almost always confined to one or two survey areas. Where they occurred at two or more survey areas, these were generally adjacent. The scattered singleton exceptions may indicate taxonomic problems which could not be resolved with the available collections; and

3. Assemblages 28 and 29 occurred on saline claypans at widely separated locations.
To reduce the influence of localised 'endemism' on the analysis outcome, assemblages 5 to 27 and 30 were removed from the data-set. When the reduced matrix was re-analysed, the allocation of quadrats among dendrogram partitions (Figure 4) were more geographically consistent than the allocation derived using the entire data-matrix (Figure 2): KE1 and KE2 were allocated with the remainder of the central and northern quadrats, while PE3, PE4 and NA2 were allocated with the rest of the southern quadrats.

'Precipitation in the coldest Quarter' (PcldQ) in conjunction with 'soil exchangeable Sodium' (exNa) provided the best statistical separation of the five groups defined in Figure 4 (see Figure 5), although the gradient in 'soil carbon' conformed most closely

Annual Average Precipitation (mm) (Kruskal-Wallis $\mathrm{H}=35.7 \mathrm{df}=4 \quad \mathrm{p}=0.0000)$

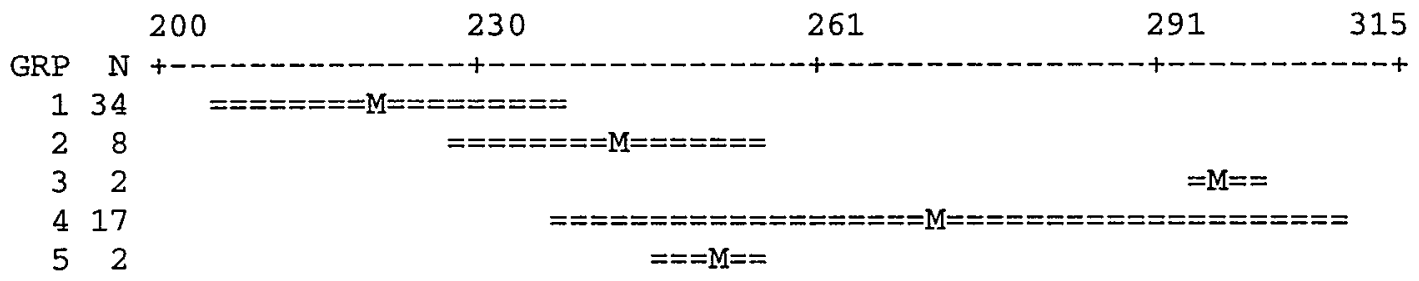

Soil Potassium (ppm) (Kruskal-Wallis $\mathrm{H}=41.8 \mathrm{df}=3 \mathrm{p}=0.0000$ )

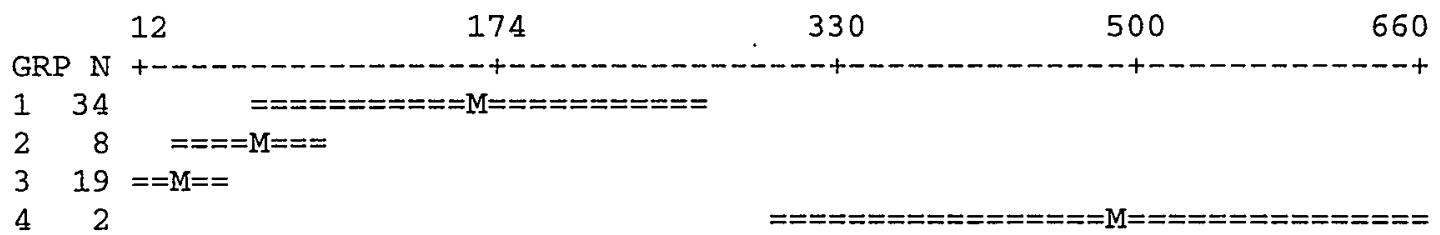

Soil Exchangeable Magnesium (me\%) (Kruskal-Wallis $\mathrm{H}=23.3 \mathrm{df}=3 \mathrm{p}=0.0000$ )

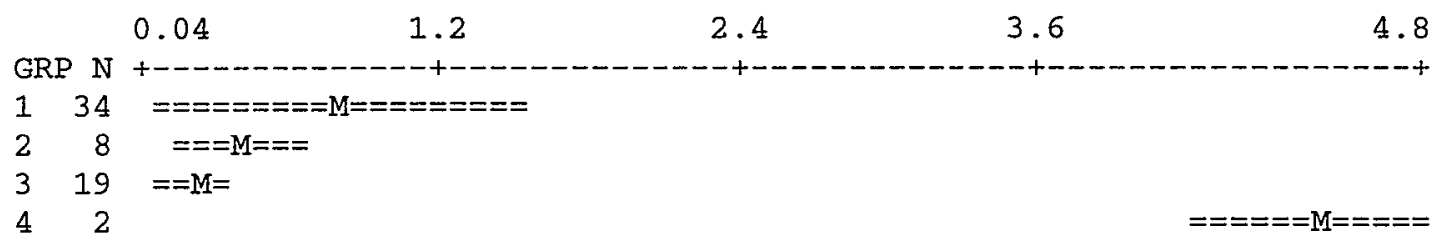

Soil Exchangeable Sodium (me\%) (Kruskal-Wallis $\mathrm{H}=11.8 \mathrm{df}=3 \mathrm{p}=0.0081$ )

0.01

7.3

14.6

21.8

29.2

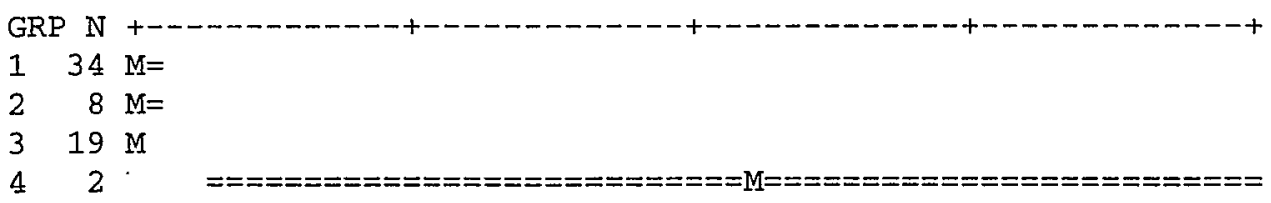

Figure 3 Average environmental attribute values for the quadrat groups defined in Figure 2. Bars indicate standard deviations about the mean (M); GRP = classification group number in Figure 2; $N=$ number of quadrats in each classification group. 


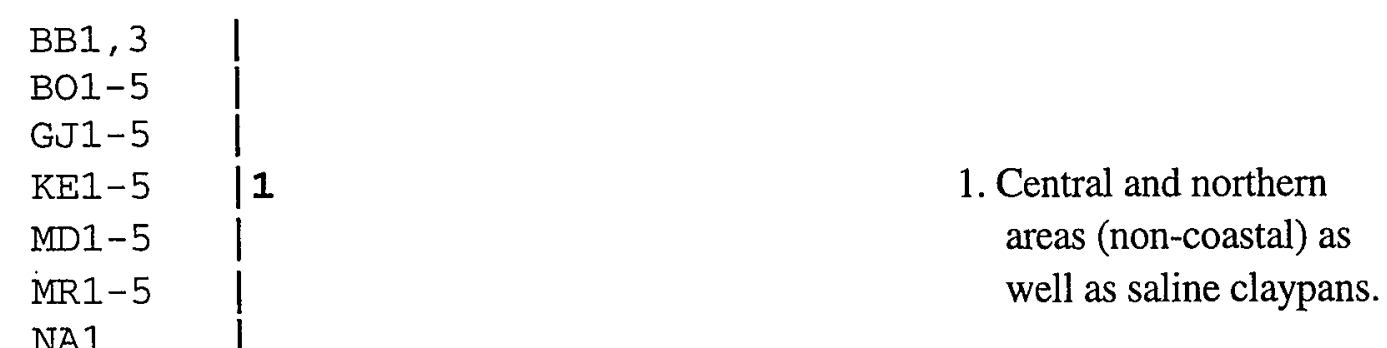

2. Central coastal sands

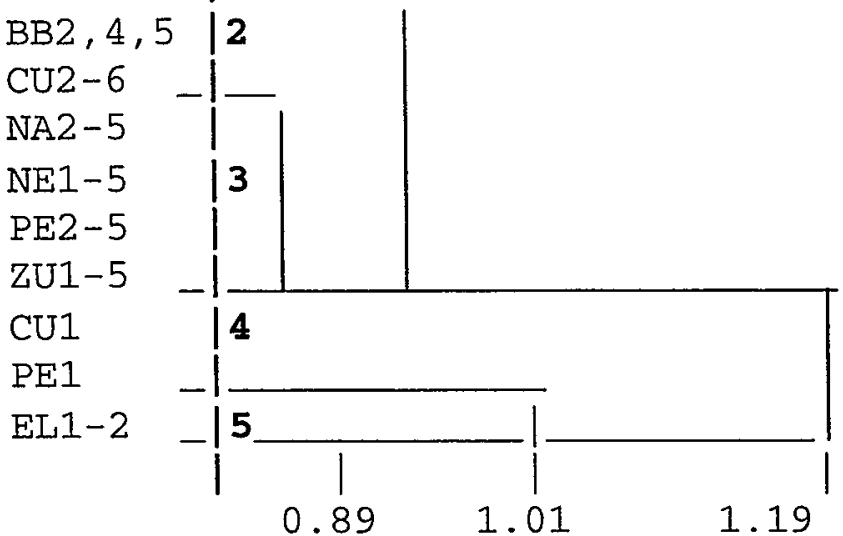

3. Southern sands

4. Saline claypans high in gypsum

5. Edel Land dunes

\section{Coefficient of dis-similarity}

Figure 4 Quadrats classified according to similarities in their species composition, excluding species assemblages-5 to -27 and assemblage-30 (the strongly localised species; see text). Dendrogram structure is displayed to the 5group level.

with dendrogram structure at this level. Although PcldQ and exNa were not intercorrelated $\left(R^{2}=0.02\right.$, $\mathrm{p}=\mathrm{NS})$, 'soil potassium' (K(HCO3)) was tightly inter-correlated with $\mathrm{PcldQ}\left(\mathrm{R}^{2}=-0.36, \mathrm{p}<0.001\right)$, and 'soil exchangeable Magnesium' (exMg) with exNa $\left(R^{2}=0.52, p<0.0001\right)$. Since PcldQ and 'annual average precipitation' (Pann) are also tightly inter-correlated $\left(\mathrm{R}^{2}=0.71, \mathrm{p}<0.0001\right)$, these results are consistent with the physical attributes identified using the entire data-set (described above).

\section{Vicariant Patterns}

Spiders have been the focus of many broad-scale biogeographic studies, some of which have demonstrated significant vicariant distribution patterns, especially at the continental scale (e.g. Platnick, 1976). The data presented here was scrutinised to determine whether any vicariant patterns were evident between two or more species within individual genera.

The two Carnarvon species of the clubionid Meedo were found to be disjunctly distributed with $M$. houstoni found in the central and northern quadrats (BB, BO, GJ, KE, MD, MR, NA and WO) with the most southerly record at NA1, and $M$. sp. 1 only in the southern quadrats at EL and ZU. This pattern follows the division between the Southwest and the Eremaean Botanical Provinces.
The two species of Miturgidae Genus 1 were well represented amongst the samples and were completely allopatric, the former in five northern survey areas ( $\mathrm{BO}, \mathrm{KE}, \mathrm{GJ}, \mathrm{BB}$ and $\mathrm{MD}$ ) and the latter in four southern survey areas (PE, WO, NA and NE). No specimens of this genus were collected at $\mathrm{CU}, \mathrm{MR}, \mathrm{EL}$ or ZU.

The six species of Miturgidae Genus 2 were found in varying regions of the study area. Genus 2, sp. 1 was disjunctly distributed in the north (CU and MR) and the south (WO, NA, NE and ZU). Genus 2, sp. 2 and sp. 6 were widespread throughout the survey areas north of the mulga-eucalypt line, with the most southerly occurrence of sp. 2 at NA2 and that of sp. 6 at NA1, which are situated on the boundary between the Southwest and the Eremaean Botanical Provinces. Conversely, Genus 2, sp. 3 was found at two near-coastal survey areas within the Southwest Botanical Province at EL and ZU. Genus 2, sp. 4 and 5 were restricted to northern areas, with the former at $C U$ and $M R$, and the latter at $B O$.

Species of Miturga also possessed varying distribution patterns. Miturga sp. 2 was widespread in all survey areas except GJ, MD and EL. Miturga sp. 3 was patchily distributed in $\mathrm{MR}, \mathrm{KE}$ and $\mathrm{BB}$, while $M$. agelenina (Simon) was found to be disjunct at BB and ZU. Miturga sp. 1 was found in all survey areas of the Eremaean Botanical Province except $\mathrm{CU}$, with the most southerly occurrence at NA2 

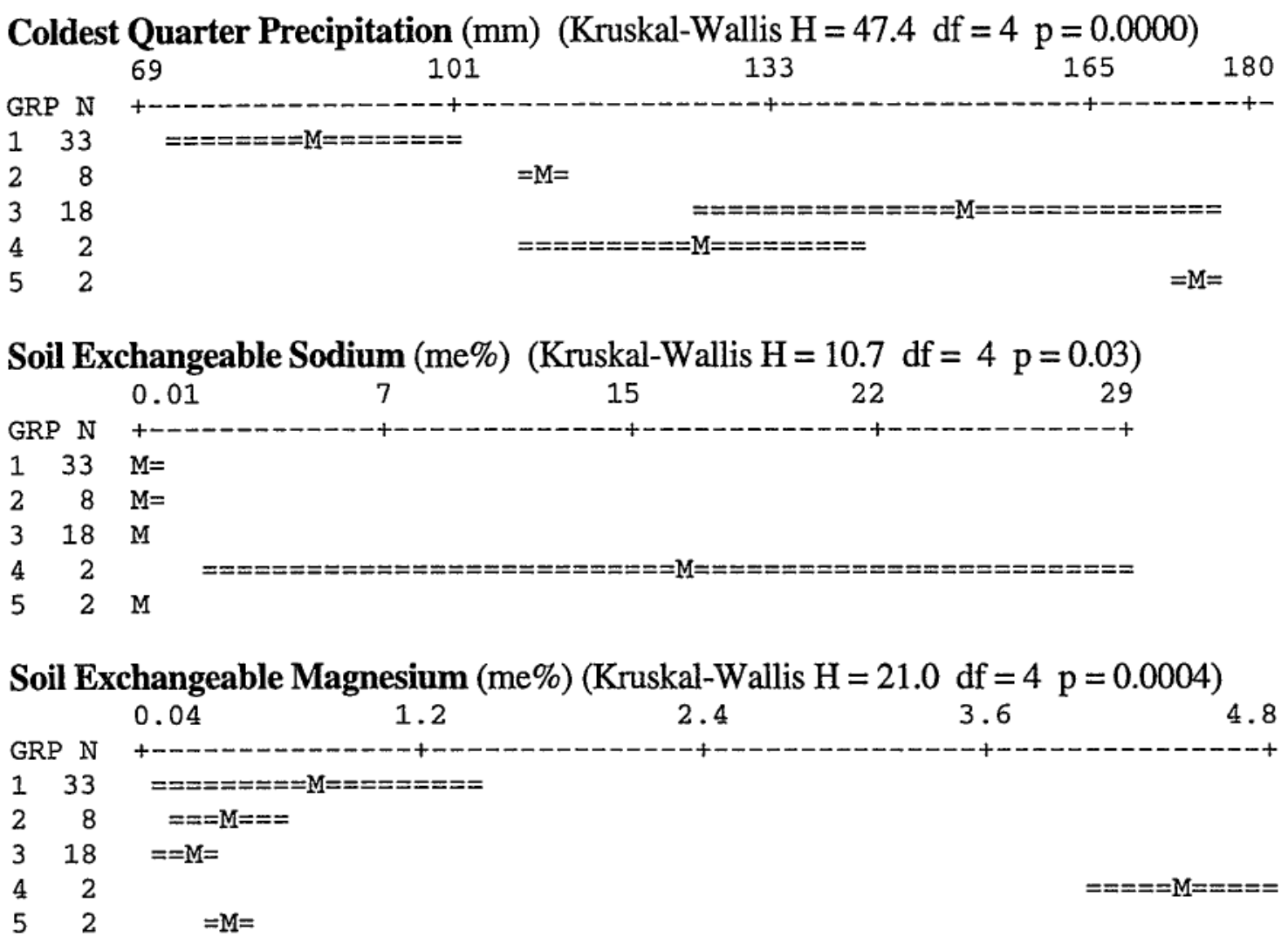

Soil Organic Carbon (ppm) (Kruskal-Wallis $\mathrm{H}=30.7 \mathrm{df}=4 \mathrm{p}=0.0000$ )

\begin{tabular}{|c|c|c|c|c|c|}
\hline & 0.09 & 0.28 & 0.48 & 0.67 & 0.87 \\
\hline $\mathrm{P} N$ & +--- & --+--- & ---+- & ---+- & ----+ \\
\hline 33 & $===$ & $=====-$ & & & \\
\hline 8 & & $====\mathrm{M}=$ & & & \\
\hline 18 & & & $=====$ & & \\
\hline 2 & & & $==$ & $=====$ & \\
\hline 2 & & & & & $===M==$ \\
\hline
\end{tabular}

Figure 5 Average environmental attribute values for the quadrat groups defined in Figure 4. Bars indicate standard deviations about the mean (M); GRP = classification group number in Figure $4 ; \mathrm{N}=$ number of quadrats in each classification group.

which is situated on the boundary of the Southwest and the Eremaean Botanical Provinces. Miturga sp. 4 was only found at ZU1 within the Southwest Botanical Province and may represent a member of a more southerly distributed taxon.

Molycriinae Genus 2 (Prodidomidae) contained three species of which Genus 2, sp. 2 was found only at the northerly $\mathrm{CU}$, demonstrating total allopatry with Genus 2, sp. 1 which was widespread at all survey areas except $\mathrm{CU}$ and $\mathrm{ZU}$. The third species, Genus 2, sp. 3, was less informative, being found sporadically at $\mathrm{BO}, \mathrm{PE}, \mathrm{NA}$ and $\mathrm{ZU}$.

The three species of Prodidomus possess varying distributions with $P$. sp. 1 widespread across all survey areas except GJ, PE, NA and EL, and the allopatric P. sp. 2 found only at GJ, the most westerly site examined as part of the survey. The third species is sympatric with $P$. sp. 1 at BO3.
These patterns demonstrate that varying historical factors have probably played a significant role in spider speciation patterning across the southern Carnarvon Basin, with the divergence between southern and northern species the most obvious pattern. Less frequently observed was a west-east vicariant pattern, with the Prodidomus species the most obvious example.

\section{DISCUSSION}

Of the 53 araneomorph spider families known to possess indigenous representatives in Western Australia, eight are restricted to the temperate south-western corner (Anapidae, Archaeidae, Cycloctenidae, Malkaridae, Mimetidae, Orsolobidae, Pararchaeidae and Toxopidae), while three are known only from the northern tropical regions 
(Ochyroceratidae, Scytodidae, Tetrablemmidae - an introduced scytodid species has been found in south-western Australia). Others, such as the Symphytognathidae, are patchily distributed in Western Australia, occurring either in forest habitats in the temperate south-west (Harvey, 1992) or in caves of Cape Range peninsula (Harvey, 1998). As expected, none of these 12 families were recorded during the present survey of the semi-arid southern Carnarvon Basin.

Of the remaining 41 families which are thought to be relatively widely distributed in Western Australia, 33 were recorded in pitfall traps during the current survey (Table 2). Pitfall traps sample those portions of the fauna that are active on the ground surface, and the data presented here are not designed to represent a complete survey of the araneomorph spiders of the region. As noted above, representatives of many families which are known to occur in the survey area are underrepresented in the species recorded (Table 2). These include members of the Uloboridae which are unlikely to be found in pitfall traps due to their web-building habit, and the Hahniidae which probably do not venture far from their natural habitat of tree bark. However, pitfall traps contain a high proportion of adult males which present the most useful diagnostic features for species separation, and a low proportion of juveniles which are virtually unidentifiable due to the lack of sexual features.

The wide variety of taxa identified to date (285 species placed in 146 genera) does not include two major families, Zodariidae and Gnaphosidae, for which numerous taxa exist in the survey collections. The addition of these taxa may well alter the results presented here. We estimate that the total diversity of ground-dwelling araneomorph spiders for the survey region is likely to exceed 350 species, which is nearly three times the diversity of the reptile fauna of the region (McKenzie et al., 2000). These data are far in excess of our initial estimates of the fauna of the region, and highlight the relatively high diversity of terrestrial invertebrates in the semi-arid and arid zones of Australia.

Geographical patterns in the species composition of araneomorph spider communities across the study area were found to be correlated with environmental gradients such as rainfall, modified by a claypan floor effect (indicated by either 'soil exchangeable Magnesium' or salinity as 'soil exchangeable Sodium') (Figure 5). Magnesium accumulates in lake sediments, such as the saline claypan quadrats that comprise Group-4. Together, these correlations point to productivity as a scalar of spider assemblage composition, summarised by the observed gradient in soil organic carbon (see Figure 5) which is a surrogate for other variables such as vegetational cover. However, in the absence of data on the ecological niches of most Carnarvon Basin araneomorph spiders, the environmental correlates with their patterns of occurrence across the study area that are identified in this paper should not be treated as causal.

It is clear that the most disparate quadrats, in terms of species composition, were situated at the southern end of the study area. This is entirely consistent with the floral attributes of the region (Beard, 1980), and indicates that the araneomorph spider assemblages of this region shows marked differences to that in the Eremean Botanical Province to the north. More work is needed to analyse the spider fauna in relation to areas to the south of the study area, but it is likely that assemblages detected in the southern quadrats will also be found further south of the study area.

As noted above, many pairs of species were found to possess allopatric distribution patterns, suggesting that they have evolved in situ due to either low mobility or in response to local soil and climatic variation. Examples include the clubionid Meedo, the miturgids Miturga, Genus 1 and Genus 2, and the prodidomids Prodidomus and Genus 2. These strongly localised patterns of endemism were particularly noticeable in the southern survey areas and in quadrats with extreme environmental conditions, such as the saline claypans and the scree slopes of the Kennedy Ranges. However, the wider implications of these observed trends in disjunct distributions and local endemism cannot be fully assessed without more detailed collecting of spiders in regions adjacent to the study area, and the completion of suitable taxonomic revisions of the taxa involved.

The total patterning found in the assemblages (Table 3) were related to environmental gradients as well as in situ evolutionary processes which can only be more fully assessed as the identity, historical relationships and ecological niches of the Australian spider fauna become more fully understood.

\section{Spiders in biogeographical surveys}

Spiders are a dominant component of the biodiversity of most terrestrial habitats (Coddington and Levi, 1991) and are a useful tool in biogeographic and ecological studies (Churchill, 1996). They are easy to collect in a standardised fashion utilising pitfall traps and most of the specimens collected in this way are adults, which can then be efficiently classified at the species level, despite the lack of taxonomic revisions and publications for many groups. The results presented herein suggest that araneomorph spiders can provide a fine-grained perspective of biodiversity patterns across a wide geographic area. 
Table 3 Entire data matrix reordered according to species co-occurrences at the same quadrats and similarities in the overall species composition of the quadrats. Quadrat codes are printed vertically, and dendrogram partitions at the 17-group level are coded 'A-Q'.

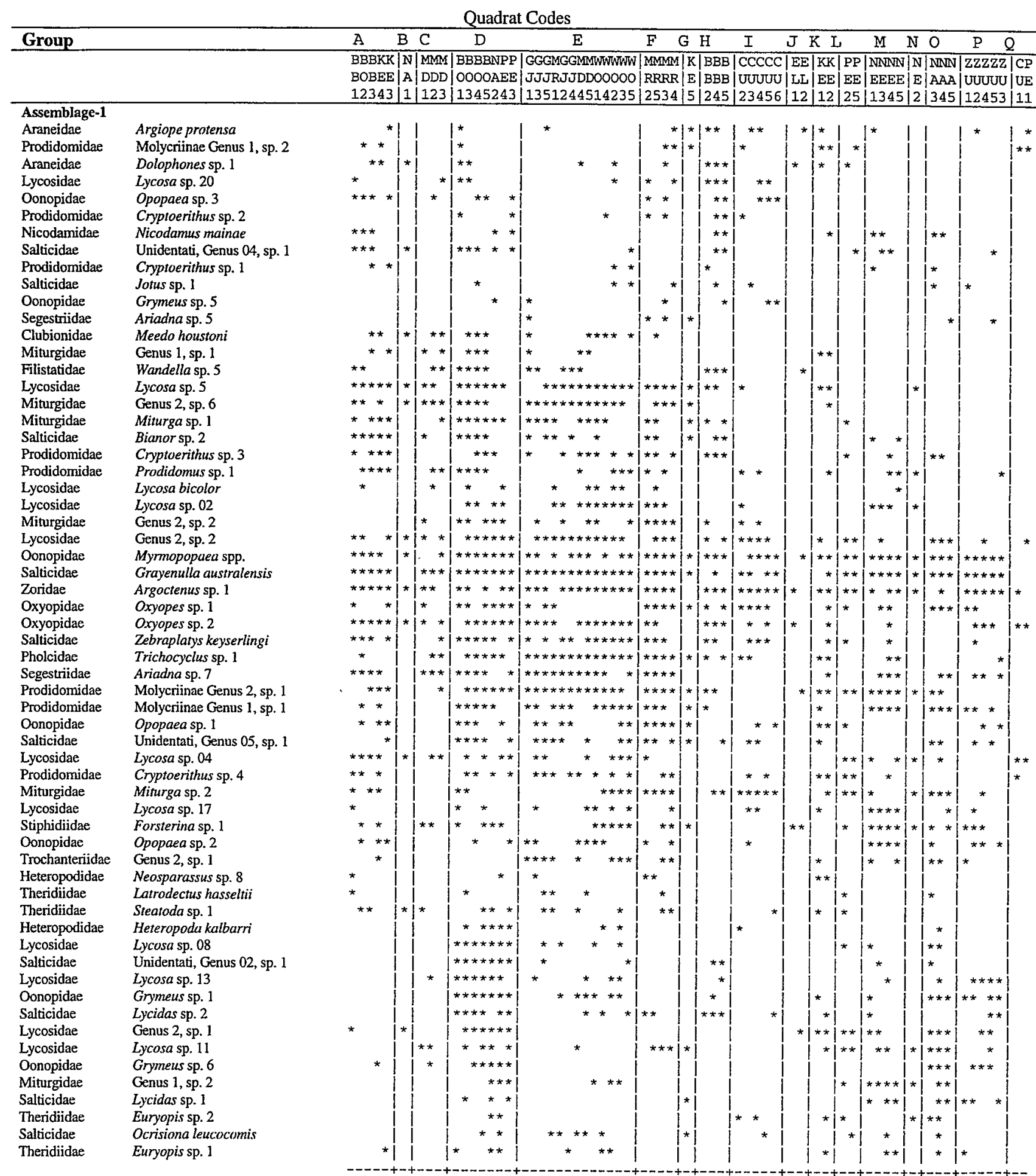


Table 3 (cont.)

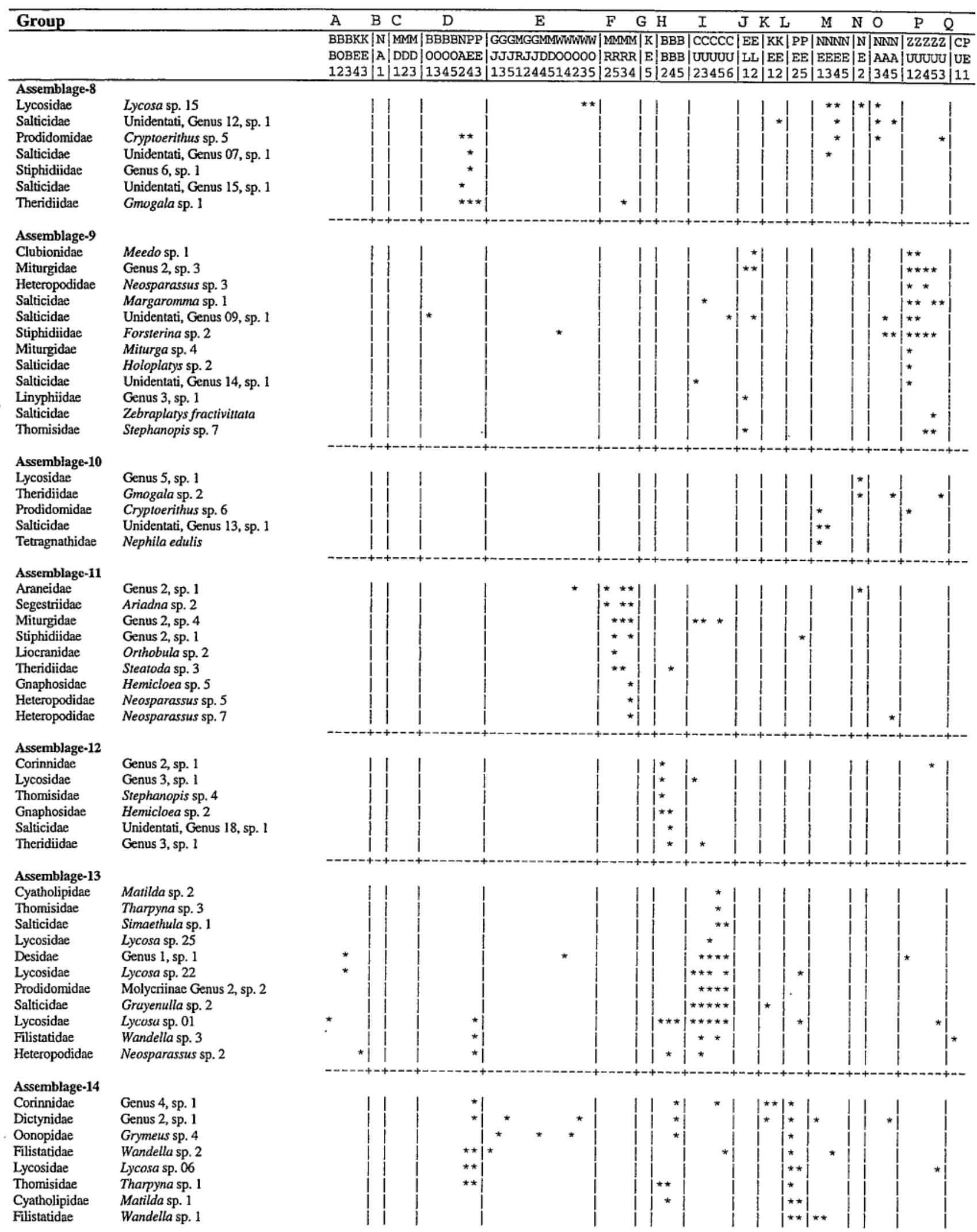




\section{ACKNOWLEDGEMENTS}

Funding for this project was provided by the Commonwealth through the National Reserves System Co-operative Program of the Australian Nature Conservation Agency (now Environment Australia), together with State funds provided by the Department of Conservation and Land Management and the Western Australian Museum. We wish to thank our fellow 'surveyors' who assisted us during the field program, Mike Lyons for Figure 1, Norm McKenzie for assistance with the numerical analyses and for significant input into the manuscript, and Ric How, Tracey Churchill and an anonymous referee for extremely useful comments on a draft of the manuscript. Robert Raven, Norman Platnick, Barbara Main, Vladimir Ovtsharenko, Cor Vink and Mike Gray very kindly assisted with identifications and advice concerning placement of problematic taxa - we trust that we have not gezumped any of their results!

\section{REFERENCES}

Baehr, B. and Baehr, M. (1987). The Australian Hersiliidae (Arachnida: Araneae): taxonomy, phylogeny, zoogeography. Invertebrate Taxonomy 1: 351-437.

Baehr, B. and Baehr, M. (1992). New species and new records of genus Tamopsis Baehr \& Baehr, (Arachnida, Araneae, Hersiliidae). Third supplement to the revision of the Australian Hersiliidae. Records of the Western Australian Museum 16: 61-77.

Baehr, B. and Baehr, M. (1993). New species and new records of Hersiliidae from Australia, with an updated key to all Australian species (Arachnida: Araneae: Hersiliidae). Fourth supplement to the revision of the Australian Hersiliidae. Records of the Western Australian Museum 16: 347-391.

Beard, J.S. (1976). Vegetation Survey of Western Australia Murchison 1:1000 000 vegetation series. University of Western Australian Press, Perth.

Beard, J.S. (1980). A new phytogeographic map for Western Australia. Western Australian Herbarium Research Notes 3: 37-58.

Beard, J.S. (1990). Plant Life of Western Australia. Kangaroo Press, Kenthurst.

Belbin, L. (1993). PATN: pattern analysis package. CSIRO, Canberra.

Churchill, T.B. (1996). Coastal heathland spiders: spatial distribution and biogeographic significance. Records of the Queen Victoria Museum and Art Gallery 103: 151158.

Churchill, T.B. (1999). Measuring spider richness: effects of different sampling methods and spatial and temporal scales. Journal of Insect Conservation 3: 287295.

Coddington, J.A. and Levi, H.W. (1991). Systematics and evolution of spiders (Araneae). Annual Review of Ecology and Systematics 22: 565-592.

Davies, V.T. (1994). The huntsman spiders Heteropoda
Latreille and Yiinthi gen. nov. (Araneae: Heteropodidae) in Australia. Memoirs of the Queensland Museum 35: 75-122.

Gray, M.R. (1994). A review of the filistatid spiders (Araneae: Filistatidae) of Australia. Records of the Australian Museum 46: 39-61.

Harvey, M.S. (1992). A new species of Symphytognatha Hickman (Araneae: Symphytognathidae) from Western Australia. Records of the Western Australian Museum 15: 685-689.

Harvey, M.S. (1995). The systematics of the spider family Nicodamidae (Araneae: Amaurobioidea). Invertebrate Taxonomy 9: 279-386.

Harvey, M.S. (1998). A review of the Australasian species of Anapistula Gertsch (Araneae: Symphytognathidae) Records of the Western Australian Museum 19: 111-120.

Henschel, J.R., Davies, V.T. and Dickman, C.R. (1995). The slit spider (Araneae: Clubionoidea) that constructs fissures in the sand dunes of the Simpson Desert, central Australia. Journal of Natural History 29: 137-145.

Hirst, D.B. (1989). A revision of the genus Pediana Simon (Heteropodidae: Araneae) in Australia. Records of the South Australian Museum 23: 113-126.

Hirst, D.B. (1991). Revision of Australian species of the genus Holconia Thorell (Heteropodidae: Araneae). Records of the South Australian Museum 24: 91-109.

Jocqué, R. and Baehr, M. (1992). A revision of the Australian spider genus Storena (Araneae: Zodariidae). Invertebrate Taxonomy 6: 953-1004.

Keighery, G.J., Gibson, N., Lyons, M.N. and Burbidge, A.H. (2000). Flora and vegetation of the southern Carnarvon Basin, Western Australia. Records of the Western Australian Museum, Supplement No. 61: 77154.

Koch, L. (1873). Die Arachniden Australiens. Vol. 1. Bauer and Raspe, Nürnberg.

Levi, H.W. (1983). The orb-weaver genera Argiope, Gea and Neogea from the western Pacific region (Araneae: Argiopinae, Araneidae). Bulletin of the Museum of Comparative Zoology 150: 247-338.

Main, B.Y. (1987). A new genus of clubionoid spider from Western Australia (Arachnida: Araneomorphae). Australian Entomological Magazine 13: 77-81.

McKay, R.J. (1973). The wolf spiders of Australia (Araneae: Lycosidae): 1. the bicolor group. Memoirs of the Queensland Museum 16: 375-398.

McKay, R.J. (1975). The wolf spiders of Australia (Araneae, Lycosidae). 5. Two new species of the bicolor group. Memoirs of the Queensland Museum 17: 313-318.

McKay, R.J. (1979). The wolf spiders of Australia (Araneae: Lycosidae): 12. Descriptions of some Western Australian species. Memoirs of the Queensland Museum 19: 241-275.

McKenzie, N.L., Rolfe, J.K., Aplin, K., Cowan, M. and Smith, L.A. (2000). Herpetofauna of the southern Carnarvon Basin, Western Australia. Records of the Western Australian Museum, Supplement No. 61: 335360.

McMahon, J.P., Hutchinson, M.F., Nix, H.A. and Ord, K.D. (1995). ANUCLIM Users Guide, Version 1. Centre 
for Resource and Environmental Studies, Australian National University, Canberra, Australia.

Michaelsen, W. and Hartmeyer, R., Eds. (1907-1908). Die Fauna Südwest-Australiens. Gustav Fischer, Jena.

Platnick, N.I. (1976). Drifting spiders or continents? Vicariance biogeography of the spider subfamily Laroniinae (Araneae, Gnaphosidae). Systematic Zoology 25: 101-109.

Platnick, N. I. (1997). Advances in Spider Taxonomy 1992 1995, with redescriptions 1940-1980. New York Entomological Society, New York.

Platnick, N.I. (2000). A relimitation and revision of the Australasian ground spider family Lamponidae (Araneae: Gnaphosoidea). Bulletin of the American Museum of Natural History 254: 1-\$\$\$

Simon, E. (1908). Araneae, $1^{\text {re }}$ partie. In W. Michaelsen and R. Hartmeyer eds), Die Fauna Sïdwest-Australiens, Vol. 1: 359-446. Gustav Fischer, Jena.

Simon, E. (1909). Araneae, $2^{\text {me }}$ partie. In W. Michaelsen and R. Hartmeyer (eds), Die Fauna SüdwestAustraliens, Vol. 2: 155-212. Gustav Fischer, Jena.

Sneath, P.H.A. and Sokal, R.R. (1973). Numerical Taxonomy: The Principles and Practice of Numerical Classification. Freeman, San Francisco.

Waldock, J.M. (1991). The colour-forms of the Christmas Spider Gasteracantha minax in south-western Australia. Western Australian Naturalist 18: 207-215.
Wyrwoll, K.-H., Courtney, J. and Sandercock, P. (2000). The climatic environment of the Carnarvon Basin, Western Australia. Records of the Wéstern Australian Museum, Supplement No. 61: 13-27.

Wyrwoll, K.-H., Stoneman, T., Elliott, G. and Sandercock, P. (2000). The geoecological setting of the southern Carnarvon Basin: geology, geomorphology and soils of selected sites. Records of the Western Australian Museum, Supplement No. 61: 29-75.

Żabka, M. (1990). Salticidae (Arachnida: Araneae) of Oriental, Australian and Pacific regions, IV. Genus Ocrisiona Simon, 1901. Records of the Australian Museum 42: 27-43.

Żabka, M. (1991). Salticidae (Arachnida: Araneae) of Oriental, Australian and Pacific regions, V. Genus Holoplatys Simon, 1885. Records of the Australian Museum 43: 171-240.

Żabka, M. (1992a). Salticidae (Arachnida: Araneae) of Oriental, Australian and Pacific regions, VII. Paraplatoides and Grayenulla - new genera from Australia and New Caledonia. Records of the Australian Museum 44: 165-183.

Żabka, M. (1992b). Salticidae (Arachnida: Araneae) of Oriental, Australian and Pacific regions, VIII. A new genus from Australia. Records of the Western Australian Museum 15: 673-684.

Manuscript received 8 October 1999; accepted 30 May 2000. 